\title{
DESIGN OF STAINLESS STEEL SECTIONS WITH CIRCULAR OPENINGS IN SHEAR
}

\author{
R Mark Lawson ${ }^{1}$, Antoine Basta ${ }^{2}$ and Asraf Uzzaman ${ }^{3}$ \\ 1. University of Surrey, Guildford GU2 7XH, UK \\ 2. MLM Consulting Engineers Ltd, London \\ 3. KTP Research associate, University of Strathclyde \\ Corresponding author: m.lawson@surrey.ac.uk
}

\section{Summary}

This paper addresses the design of stainless steel sections with large circular openings subject to shear and bending. A total of 9 tests on pairs of $C$ sections using 2 and $3 \mathrm{~mm}$ thick stainless steel in austenitic 1.4301 and lean duplex 1.4162 grades was performed. The tests showed that the shear resistance at an opening is controlled by local compression at a radial cross-section at approximately $25^{0}$ to the vertical. For closely spaced openings, the angle of highest stress increases to about $65^{0}$ to the vertical. The shear resistance of a Class 4 web is also affected by local buckling around the opening, which is a function of its diameter to steel thickness ratio. An equilibrium model is presented which predicts the normal stress on the radial planes around an opening. A simplified formula for the local buckling strength around circular web openings is also presented, which agrees well with the test results. 


\section{Introduction}

Stainless steel beams may be perforated by circular or other shapes of openings for visual reasons, to reduce their weight, and to pass services through. Furthermore, stainless steel sections are often relatively thin, in order to economise on materials use, and so the effect of large openings can lead high stresses around the openings and to local buckling of the web, which reduces the bending and shear resistance of the members.

The relevant standard for selection of stainless steel is BS EN 10088 (BSI-2009), and the designation system is the European steel number and steel name. Standard stainless steel grades like 1.4301 (popular name of 304) and 1.4401 (316) are now extended by the greater use of duplex grades, which are higher strength and are advantageous in general building applications. Lean duplex grades, which are low in nickel content, have the mechanical properties of duplex grades and are increasingly used in structural applications, but are not covered by the design standard for stainless steel, BS EN 1993-1-4 (BSI-2006).

Various shapes of web openings in all types of steel sections are illustrated in Figure 1 and circular openings are the subject of this paper. Other forms of opening may be triangular or diamond shaped, and multiple slots have been shown to reduce the heat flux through the section. Rectangular openings may be used where services pass through the beams, and this case is covered by the existing theory on large web openings.

Figure 1 Various forms of web openings in stainless steel beams 
An important structural application of stainless steel is in balcony beams that project from inside the building and therefore potentially lead to thermal bridging. When a stainless steel beam is perforated by circular openings of about $70 \%$ of the section depth, it is found that the heat flow through the beam, combined with the low thermal conductivity of stainless steel, is reduced by about $85 \%$ relative to an equivalent galvanised steel section. In cantilever balcony beams, high shear acts together with high bending moment and closely spaced openings can also result in web-post buckling between the openings. Therefore, in the absence of guidance on stainless steel sections with large circular openings, there is need to develop simplified rules or to adapt existing rules for use in this and other applications.

\section{Design of Beams with Large Web Openings}

The design of hot rolled steel sections and composite beams with large rectangular web openings is based on the transfer of shear by Vierendeel bending of the webflange Tee sections at the four 'corners' of the opening. The plastic resistance of the Tees can be developed in Class 1 and 2 steel sections, whose definition is based on the width to thickness of the elements of the cross-section. These limits are presented in EN1993-1-1 :Eurocode 3 (BSI- 2005).

The early work on hot rolled steel beams with circular web openings was carried out in Canada (Redwood, 1973). It was shown that an isolated circular opening could be treated as an equivalent rectangle for Vierendeel bending in which the effective length of the opening is taken as $0.45 \mathrm{x}$ opening diameter and its depth as $0.9 \mathrm{x}$ diameter. An alternative approach for circular openings is called the Sahmel's method, which is based on equilibrium of the local stresses on radial planes around the opening (Sahmel, 1969). However, this method does not apply to closely spaced openings when limited by the stresses in the web-post between the openings. 
This work was extended into the field of composite beams with rectangular openings (Darwin, 1990), and it was found that composite action greatly increased the transfer of shear across the opening. The SCI/CIRIA recommendations (Lawson, 1989) provided the guidance on composite beams with web openings, and in 1990, SCI P 100 provided guidance on cellular beams with circular openings (Ward, 1990). This was based on detailed finite element studies of the buckling of the web-post in noncomposite cellular beams. The approach in SCI P100 for cellular beams is based on solving for equilibrium at $5^{\circ}$ intervals around the openings.

More recently, an ECSC project (European Commission, 2006) provided guidance on composite beams with large web openings, which was calibrated against the failure loads of four $7 \mathrm{~m}$ span cellular beams with closely spaced circular openings, and four plate girder tests on composite and non-composite sections. In these tests, the web depth to thickness ratio was about 90 , which meant they were potentially subject to web buckling. Despite this high slenderness, it was found that the plastic bending resistance of the web-flange Tees could be developed in Vierendeel bending at the openings.

Design guidance for steel and composite beams with large web openings was presented in SCI Publication 355 (Lawson, 2011), and was based on the application rules of BS EN 1993-1-1 (BSI- 2005).and BS EN 1994-1-1: Eurocode 4 (BSI2005(2)). The model for web-post buckling was based on an equivalent 'strut' approach using a formula for the effective length of the web-post as a function of the depth and the edge to edge spacing of the openings. The SCl method for hot rolled steel sections is compared later to the method developed in this paper for Class 4 sections. 
Although considerable test data exists on Class 1 and 2 hot rolled steel sections, there is little data or design guidance on Class 3 or 4 stainless steel or galvanised steel cold formed members with large openings, particularly using higher strength grades. These sections are strongly influenced by the local buckling of the web. Furthermore, local buckling of stainless steel sections is influenced by the less well defined yield point of many types of stainless steel.

A series of papers by Moen and Schafer $(2009,2011)$ addressed the behaviour of C sections with holes acting in compression that are mainly used in racking systems. Analytical predictions for the buckling strength of both perforated webs and flanges of C sections in compression were compared with finite element analyses. A variety of opening shapes, such as circular, square, elongated and slotted shapes were considered and it was shown that for circular openings, the elastic critical buckling stress tends to a value of about $70 \%$ of that of the un-perforated plate (Moen, 2009). A series of tests on perforated $\mathrm{C}$ sections in compression was carried out, and in a further paper (Moen, Schudlich and von der Heyden, 2013), tests were carried out of joists with openings in bending. The design approach for perforated sections was presented in terms of the Direct Strength Method (AISI, 2009) in which the compression resistance can be expressed in terms of the critical buckling strength.

\section{Previous Research on Stainless Steel in Structural Applications}

A review of the uses of stainless steel in construction (Baddoo, 2008) identified the important challenges and research needs. In the context of Eurocodes, BS EN 19931-4 Design of steel structures, Supplementary rules for stainless steels extends the application of BS EN 1993-1-1 (covering general rules for the structural design of building-type structures from hot rolled and welded carbon steel sections) and EN 1993-1-3 (covering design of cold-formed light gauge carbon steel sections) to hot 
rolled welded and cold-formed stainless steels. EN 1993-1-4 has recently completed its first revision and uses recent research information that has helped to improve its design provisions. Other information on the structural design of stainless steel is given in a Eurolnox/ SCI publication (2006) and in a recent AISC Guide (2014).

The stress-strain characteristics of stainless steels are non-linear and also stainless steels possess a high ultimate tensile strength in comparison to carbon steels. Therefore the post-elastic characteristics of stainless steels are important in understanding their structural behaviour. Real, Arrayago, Mirambell and Westeel (2014) reviewed the use of the Ramberg-Osgood expression for representation of the stress-strain curves for all types of stainless steel, which builds on previous work. It has led to the expressions given in EN1993-1-4.

The effective widths of Class 4 stainless steel elements currently in EN 1993-1-4 are less than for carbon steel, but the revision to EN 1993-1-4 has led to a general harmonisation with the equivalent carbon steel limits in EN 1993-1-1. A new approach to section classification was proposed by Gardner and Theofanous (2008).

Studies of high strength austenitic steels by cold working were made by Gardner, Talja and Baddoo (2006). More recently, tests on lean duplex stainless steels used in beams and columns were carried out by Theofanous and Gardner $(2009,2010)$. Four structural hollow section sizes from $60 \times 60 \times 3 \mathrm{~mm}$ to $100 \times 100 \times 4 \mathrm{~mm}$ thick were tested for which the average $0.2 \%$ proof strength was $633 \mathrm{~N} / \mathrm{mm}^{2}$. Bending tests on short span beams had a test resistance to plastic bending resistance ratio of 1.15 to 1.39. Based on this research, it was concluded that the flange width: thickness ratio corresponding to the Class 2 and 3 limits in EN 1993-1-4 could be increased. 
The column tests had a slenderness ratio $\bar{\lambda}$ of 0.57 to 2.0 . It was concluded that the best prediction using the design method in EN 1993-1-4 was obtained by an imperfection parameter $\alpha=0.49$ (buckling curve 'c') and a slenderness cut-off of $\bar{\lambda}_{\text {o }}$ $=0.4$. This is now incorporated into the revision of EN1993-1- 4. Recently, a wide range of tests on cold formed lean duplex columns has been investigated in detail (Huang and Young, 2014).

For channel sections failing in lateral torsional buckling, the buckling curve in EN 1993-1-4 has been revised to use an imperfection parameter $\alpha=0.35$ (buckling curve 'b') and a slenderness cut-off of $\bar{\lambda}_{0}=0.4$. The comparative buckling curves for lateral torsional buckling of channel and welded sections are illustrated in Figure 2.1. The buckling resistance of stainless steel channel sections is now higher for than for carbon steel of the same steel grade.

The shear buckling resistance of stainless steel beams was investigated (Saliba et al, 2014) by 34 tests on stainless steel plate girders to determine the effect of 'tension field' action with a rigid end post. Proposals were made for improved shear buckling formula in EN1993-1-4.

Tests on web crippling of $\mathrm{C}$ and square hollow sections beams subject to local loads are presented (Bock and Real, 2014), which proposed a modification to the web crippling formulae in EN1993-1-3 (also used in EN1993-1-4) for loading close to the support and internally within the span.

Figure 2 Lateral torsional buckling curves for stainless steel and carbon steel to Eurocode 3 


\section{Bending Tests on $\mathrm{C}$ sections with Circular Openings}

In this research programme, stainless steel beams comprising pairs of $\mathrm{C}$ sections with circular openings were loaded in shear and bending, as shown in Figure 3 . The dimensions were chosen so that shear stresses around and between the openings would be dominant failure mode. The $\mathrm{C}$ sections were $210 \mathrm{~mm}$ deep and $70 \mathrm{~mm}$ flange width with $27 \mathrm{~mm}$ deep edge stiffeners, and were delivered by the sponsors of this research. Load was applied through $100 \mathrm{~mm}$ square steel blocks via $20 \mathrm{~mm}$ diameter through bolts acting in shear, so that the load was transmitted directly to the web rather than to the flange of the section in order to avoid web crushing and local flange buckling.

The span of the beams was approximately $1.6 \mathrm{~m}$ and the opening diameter was $150 \mathrm{~mm}$, for which three opening configurations were chosen, as shown in Figure 4. A $250 \mathrm{~mm}$ edge to edge spacing of the openings represents the case of an isolated opening, whereas $50 \mathrm{~mm}$ edge to edge spacing represents the case of closely spaced openings. In this second case, failure of the web-post between the openings would occur at a lower load than that of an isolated opening. An intermediate spacing of $100 \mathrm{~mm}$ was also selected as this would probably be at the limit of the case of an isolated opening for this opening diameter.

Two stainless steel types were selected for the tests, an austenitic grade 1.4301 in thicknesses of $2 \mathrm{~mm}$ and $3 \mathrm{~mm}$, and a higher strength lean duplex grade 1.4162, (trade name LDX 2101(R)-Outukumpu data sheet, 2009) in a thickness of $2 \mathrm{~mm}$. The $2 \mathrm{~mm}$ thick steels were expected to fail elastically by local buckling around the openings, whereas the $3 \mathrm{~mm}$ thick austenitic steel might fail in a more elasto-plastic manner. 
Figure 3 Test arrangement for a pair of C sections with a central point load (Test 1 shown)

Figure 4 Details of web opening positions in the tests

Deflections were recorded of the beam web at the jack position and the tips of the flanges and also at the supports. The first load cycle to approximately $30 \mathrm{kN}$ was carried out in order to cause the bolts to slip into bearing in shear, and the second load cycle was carried out to failure. The tests were carried out under displacement control so that they could show the effects of local buckling without leading to rapid failure. The rate of displacement was selected as $0.5 \mathrm{~mm}$ per minute. The eventual failure load varied from 39 to $86 \mathrm{kN}$ for the pair of $\mathrm{C}$ sections.

The results of all 9 tests are summarised in Table 1. Two of the tests were duplicated (tests 1 and 9, and tests 6 and 8) and the difference in the failure loads between the pairs of tests was less than $5 \%$, which shows that the results are not unduly sensitive to the test regime.

The tests failed in three distinct modes depending on the spacing of the openings and the way in which the load was introduced. These modes were;

1. Vierendee/ bending failure associated with local buckling in the compression zone around the openings- see Figure 5. This occurred for widely spaced openings.

2. Web-post buckling failure in which the web-post rotated out of plane- see Figure 6. This was evident particularly for openings at $50 \mathrm{~mm}$ spacing.

3. Web buckling failure under the bolts at the load points - see Figure 7. This occurred for openings at $100 \mathrm{~mm}$ spacing using $2 \mathrm{~mm}$ thick steel. 
Table 1 Test series, failure loads and failure modes

In all tests, it was noted that significant flange curling occurred (i.e. the tips of the flanges had the tendency to move together), but this effect was independent of the openings. For example, at a jack displacement of $10 \mathrm{~mm}$, the additional displacement of the flange tips was of the order of $3 \mathrm{~mm}$.

The load-displacement curve for a representative test is shown in Figure 8 onwards. End slip is shown but was small. Failure occurred at a mid-span displacement of about $15 \mathrm{~mm}$ (span/100) and the un-loading curve was gradual, indicating the nonbrittle nature of local buckling of stainless steel at higher strains.

In test 2 using $3 \mathrm{~mm}$ thick steel, stresses were recorded at 10 points around the openings in order to correlate the performance with the theory developed in Section 4. These results are presented in Figures 9 and 10.

Test 3 with openings at $100 \mathrm{~mm}$ spacing failed prematurely by local buckling around the bolts connected to the central loaded block, as illustrated in Figure 7. This did not occur in test 5 of the same geometry using $3 \mathrm{~mm}$ thick 1.4301 steel, but there was evidence of local buckling at these bolts in test 4 using $2 \mathrm{~mm}$ thick lean duplex steel. It would be expected that the failure load would have been higher for test 3 in particular.

Figure 5 Mode of failure by Vierendeel bending around the isolated opening causing local buckling - Test 1 (after the test) placed on the lab floor

Figure 6: Mode of failure by web-post buckling with closely spaced openings- Test 2 with $50 \mathrm{~mm}$ opening spacing 
Figure 7: Mode of failure by local buckling failure around the bolts at the load point Test 3 with $100 \mathrm{~mm}$ opening spacing

Figure 8 Load-displacement for test 2 using 3mm thick steel and closely spaced openings

Figure 9 Local stresses measured in the test using 3mm thick 1.4301 steel with openings at $100 \mathrm{~mm}$ spacing

\section{Steel strengths}

The measured steel strengths from $20 \mathrm{~mm}$ wide coupon tests are presented in Table 2. The measured stress-strain graph for the lean duplex 1.4162 steel is presented in Figure 10. The yield points of the three specimens were not well defined and so the table presents the proof strength at $0.2 \%$ strain. This effective yield strength was used in the comparisons with the theory presented later. The ultimate tensile strength occurred at very high strains (over $20 \%$ for austenitic 1.4301 steel). The strength at $6 \%$ strain is also presented, as this indicates the degree of strain hardening that was used in the finite element models.

Table 2 Tensile test results for the stainless steels used in the tests

Figure 10 Stress-strain curve for $2 \mathrm{~mm}$ thick 1.4162 stainless steel (trade name LDX $\left.2101^{(\mathrm{R})}\right)$

\section{Comparison of Tests with Simple Theory}

The vertical shear stresses at the openings and the horizontal shear stress in the web-posts between the openings at the test failure loads are compared in Table 3, based on the dimensions to mid-thickness of the elements, and an effective height of $195 \mathrm{~mm}$ between the centroids of the web-flange Tee sections. The bending moment and shear force acting at the openings are also compared with the pure bending and pure shear resistances using the measured effective yield strengths of the steel. 
The ratio of the applied shear force at failure to the vertical shear resistance at the opening, $V / V_{V, R d}$ was in the range of 0.38 to 0.8 , and the highest ratio was obtained for the test on the isolated opening. The ratio of the applied bending moment next to the load point to the section bending resistance at the opening, $M / M_{e l, R d}$ was in the range of 0.23 to 0.63 , which shows that the bending moment was relatively low. The ratio of the horizontal shear stress to the shear strength of the web-post, $V_{h} / V_{h, R d}$ was in the range of 0.36 to 0.81 . The highest ratio occurred for test 7 on $3 \mathrm{~mm}$ thick steel with openings at $50 \mathrm{~mm}$ spacing.

The shear resistance due to Vierendeel bending around an equivalent rectangular opening of $0.45 h_{0} \times 0.9 h_{0}$ size was calculated using the elastic bending resistance of the Tee sections based on their unreduced properties and the measured steel strengths. In this comparison, the bending resistance of the Tees was multiplied by the reduction factor: $\left(1-\left(M / M_{e l, R d^{2}}\right)\right.$ representing the effect of the axial stress in the Tees due to the bending moment acting on the beam. The ratio of the applied shear force at failure to the Vierendeel bending resistance $V / V_{\text {vier,Rd }}$ of the Tees was in the range of 0.44 to 1.27 . The highest ratio occurred for test 5 on $3 \mathrm{~mm}$ thick steel and with openings at $100 \mathrm{~mm}$ spacing. This shows that the simple Vierendeel bending model of an equivalent rectangular opening is conservative for $3 \mathrm{~mm}$ thick steel and for isolated openings, but that web-post buckling becomes the mode of failure for thinner steels with closely spaced openings.

Table 3 Shear stresses and load ratios at the failure loads in the tests

\section{Simplified Theory for Forces around Circular Openings}

The behaviour of steel beams with closely spaced circular openings that are loaded in shear is strongly influenced by the high stresses around and between the openings 
that give rise to yielding for relatively stocky webs, or to local buckling in compression for slender webs. The model used to determine the stresses around an opening is based on equilibrium of forces acting on radial planes at an angle $\theta$ relative to the vertical axis at the centre-line of the opening, and is a simplification of Sahmel's method (1969). It is shown that the radial stresses vary around the opening and a critical angle for the maximum stresses may be determined.

This model of normal stresses on radial planes around the openings may be compared to the Vierendeel bending model for an equivalent rectangular opening, which is itself a simplification of the true behaviour. The model of normal stresses on radial planes can be extended to cover closely spaced openings.

For the case of high shear and small bending moment acting on the beam, a simplification of the stresses on the radial plane around widely spaced openings is illustrated in Figure 11. It may be assumed initially that the normal stresses acting on the radial plane are elastic and therefore increase linearly from a maximum at the edge of the opening to zero at the junction with the flange (point A). This is justified as the centroid of the web-flange Tee sections is close to the flange and so for simplicity of the method, it is reasonable to take the point $A$ as occurring at the flange. For stocky webs, local plasticity may occur near the edge of the opening, which will modify the linear stress distribution. The variation of compressive stress around the edge of the opening determines the tendency for local buckling. It is expected that these normal stresses will be at their highest for $\theta \approx 25$ to $30^{\circ}$ to the vertical and will reduce to zero for $\theta=90^{\circ}$.

Two cases for equilibrium of forces on any radial plane $\theta$ may be considered. The first case is when the planes for adjacent openings do not over-lap, and the second 
case is where they overlap, which is the case for closely spaced openings. The normal stress may be in compression or tension depending on the position around the opening, and may be given as a function of the vertical shear force, $V_{E d}$ and the centre to centre spacing: diameter ratio, $s / h_{o}$, of the openings.

\section{Radial plane, $\theta \leq \tan ^{-1}(s / h)$}

Equilibrium of vertical forces acting on a radial plane $\theta$ from the centre-line of the opening is defined by:

$$
0.5 V_{E d}=N_{w} \sin \theta+V_{\theta} \cos \theta
$$

Equilibrium of horizontal forces acting on the radial plane is defined by:

$$
\Delta N_{f}=N_{w} \cos \theta-V_{\theta} \sin \theta
$$

where $V_{E d}$ is the applied shear force acting on the section, which is assumed to be constant between the pair of openings.

$N_{w} \quad$ is the compression or tension force acting on the web on plane $\theta$ measured from the centre of the opening.

$V_{\theta} \quad$ is the shear force on the same plane

$\Delta N_{f} \quad$ is the increase in compression or tension force in the flange of the section at the projection of this plane.

$\theta \quad$ is the angle of the radial plane to vertical

Figure 11 Equilibrium of forces acting on plane $\theta$, when $\theta \leq \tan ^{-1}(s / h)$

Equilibrium of moments acting about point $A$ on the flange is obtained from an elastic distribution of normal stresses acting on the radial plane, as follows:

$$
0.5 V_{E d}(0.5 \mathrm{~h} \tan \theta)=\frac{2}{3} x . N_{w}
$$

$$
\text { where } x=0.5\left(\frac{h}{\cos \theta}-h_{o}\right)
$$


and $h \quad$ is the section depth

$h_{0} \quad$ is the opening diameter.

Solving equations (1) and (3) leads to the following expression for the normal force, $N_{w}$ on the radial plane:

$$
N_{w}=\left[\frac{1.5 \sin \theta}{1-\left(h_{O} / h\right) \cdot \cos \theta}\right] \cdot\left(0.5 V_{E d}\right)
$$

The shear force $V_{\theta}$ on this plane is given by:

$$
V_{\theta}=\left[\frac{1}{\cos \theta}-\frac{1.5 \sin \theta \cdot \tan \theta}{1-\left(h_{O} / h\right) \cos \theta}\right] \cdot\left(0.5 V_{E d}\right)
$$

The normal stress $\sigma$ acting on this plane at the edge of the opening is given by:

$$
\sigma=\frac{V_{E d}(1.5 \sin 2 \theta)}{h t\left[1-\left(h_{O} / h\right) \cos \theta\right]^{2}}
$$

where $t$ is the steel thickness.

It may be shown that $\sigma$ reaches its maximum value when $\theta$ is given by the following approximate equation:

$$
\theta=\cos ^{-1}\left[0.25\left(h_{O} / h\right)+0.72\right]
$$

Table 4 presents the maximum tension or compression radial stress at the edge of the opening of various sizes. For $h / h=0.7, \sigma$ is a maximum at $\theta=26^{\circ}$ to the vertical and the radial stress, $\sigma=2.58 \tau_{v}$, where $\tau_{v}$ is the vertical shear stress acting on the perforated web at the centre-line of the opening.

In comparison, the pure shear resistance of the perforated web at the centre-line of the opening and using mid-thickness dimensions is given by:

$$
V_{R d}=t\left(h-h_{O}-t\right) f_{y} / \sqrt{3}
$$

Table 4 Maximum compression stress at edge of opening as a multiple of the vertical shear stress at the opening. 
As a good approximation to equation (6) for the highest normal stress that occurs around the opening is:

$$
\sigma=4\left(h_{\circ} / h\right) \tau_{\mathrm{v}}
$$

where $\tau_{v}$ is the vertical shear stress at the centre-line of the opening

It follows that for opening diameters more than about $40 \%$ of the section depth, the maximum normal stress around the opening, $\sigma$ would exceed $f_{y}$, when $\tau_{v}$ reaches the shear stress of the reduced section.

\section{Case when $\theta>\tan ^{-1}(s / h)$}

The case illustrated in Figure 12 shows that for higher values of $\theta$, the radial planes intercept at mid-way between the openings and below the top flange. This will be the critical case for closely spaced openings. As a further simplification, point $A$ is assumed to correspond notionally to zero normal stress around the openings. The increase in the compression force in the top flange is given from overall equilibrium as $\Delta N_{f}=0.5 V_{E d}(s / h)$ at the centre-line of the web-post.

Figure 12 Equilibrium of forces acting on plane $\theta$, when $\theta>\tan ^{-1}(s / h)$

Equilibrium of horizontal forces on the radial plane is defined by:

$$
0.5 V_{E d}(s / h)=\quad N_{w} \cos \theta-V_{\theta} \sin \theta
$$

where $s$ is the centre-centre spacing of the openings.

Equilibrium of vertical forces on this plane is defined by:

$$
0.5 V_{E d}=\quad V_{v}+N_{w} \sin \theta+V_{\theta} \cos \theta
$$

where $V_{v}$ is the vertical shear force acting on the web above point A.

Equilibrium of moments on the radial plane about point $A$ is defined by: 


$$
0.5 V_{E d}(s / h) \cdot y=0.5 V_{E d} \cdot 0.5 s+N_{w} \cdot \frac{2}{3} x
$$

where $y=0.5(h-s \cot \theta)$ and $x=0.5\left(\frac{s}{\sin \theta}-h_{O}\right)$

Solving equations (10) and (12) leads to a normal force on the radial plane of:

$$
N_{w}=\frac{0.75 \cos \theta}{\left(1-\left(h_{O} / s\right) \sin \theta\right)} \cdot V_{w p}
$$

where $V_{w p}=$ horizontal shear force acting on the web-post $=V_{E d}(s / h)$.

The shear force $V_{\theta}$ acting on the radial plane is given by:

$$
V_{\theta}=\left[\frac{0.75 \cos ^{2} \theta}{\left(1-\left(h_{O} / s\right) \cdot \sin \theta\right)}-\frac{0.5}{\sin \theta}\right] \cdot V_{w p}
$$

It is a further requirement that $V_{w p} \leq V_{w p, R d}$, where $V_{w p, R d}$ is the shear resistance of the web-post between the openings, which is given by:

$$
V_{w p, R d}=t .\left(s-h_{O}\right) f_{y} / \sqrt{3}
$$

As for the previous case, the normal stress acting on plane $\theta$ may be given by: $\sigma=2 N_{w} /\left(x t_{w}\right)$ and becomes:

$$
\sigma=\frac{V_{E d^{1.5} \sin 2 \theta}}{h t\left[1-\left(h_{O} / s\right) \sin \theta\right]^{2}}
$$

It may be shown that $\sigma$ reaches its maximum value when $\theta$ is given by the following approximate equation:

$$
\theta=\sin ^{-1}\left[0.25\left(h_{O} / s\right)+0.72\right]
$$

Table 5 presents the maximum compression or tension stress at the edge of the opening as a multiple of the vertical shear stress at the centre-line of the opening, or alternatively, the horizontal shear stress acting on the web-post, where this stress is higher. It is found that openings may be treated as closely spaced when $s<h$. It follows that the critical zone for local compression stresses around the opening is at approximately $65^{\circ}$ to the vertical. 
Table 5 Maximum compression stress as a function of the vertical shear stress at the opening and the horizontal shear stress in the web-post

As a good approximation to equation (16) for the highest normal stress that occurs in around the opening for the case when the opening centre-centre spacing is less than the section depth is given by:

$$
\sigma=\frac{4 h_{O}}{h} \cdot \frac{\left[h-h_{O}\right]}{\left[s-h_{O}\right]} \tau_{\mathrm{v}} \text { for } s<h
$$

It follows that when the opening spacing is less than the section depth, the stresses in the lower part of the opening next to the web-post will be higher than the stresses at the upper part of the opening.

\section{Comparison of the Method of Normal Stress on a Radial Plane with Test Results}

The normal stresses on the radial plane around the opening using the method presented above may be calculated at the failure loads in the tests and compared to the measured steel proof strengths, $f_{y}$ at $0.2 \%$ strain. These results are presented in Table 6 . This stress ratio varies between 0.70 and 1.21 , the lower ratios occurring for the higher strength lean duplex steel, and also for test 3 which failed by web buckling in the region of the bolts.

Table 6 Maximum normal stress $\sigma$ on the critical radial plane calculated for the test failure loads

\section{Treatment of Web-post Buckling in Class 3 or 4 Sections}

Local buckling around a circular web opening is influenced by the:

- magnitude and variation of the compression stress around the opening

- opening diameter: steel thickness ratio 
- steel strength and elastic modulus (and for stainless steel, the variation of the tangent elastic modulus at higher stresses).

For an isolated opening, the beam tests and finite element analyses showed that the buckling wave extends from approximately $10^{\circ}$ to $40^{\circ}$ in an arc around the opening, which is equivalent to a perimeter length of $0.25 h_{\circ}$. To allow for the partial fixity of the ends of the wave and the elastic stress variation along the critical plane, the effective buckling length, $\ell_{w}$ around the opening may be taken with reasonable accuracy as $\ell_{w}=0.2 h_{O}$

The effective slenderness $\lambda$ of the equivalent 'strut' may be obtained by dividing by $t / \sqrt{12}$, and so:

$$
\lambda=\sqrt{12} \ell_{w} / t=0.7 h_{O} / t
$$

The slenderness ratio is defined by:

$$
\bar{\lambda}=\lambda / \lambda_{1} \text { where } \lambda_{1}=\pi \sqrt{E / f_{y}}
$$

where $\mathrm{E} \quad=\quad$ elastic modulus of the steel

$\mathrm{f}_{\mathrm{y}} \quad=\quad$ steel strength

For local buckling around the opening, it is proposed that the buckling curve ' $c$ ' in EN 1993-1-4 may be used as for cold formed stainless steel channel sections, which corresponds to an imperfection parameter, $\alpha=0.49$. This buckling curve has a cut-off in slenderness ratio of $\bar{\lambda}=0.4$, which is consistent with the revision to EN 1993-1-4.

In the normal range of $40 \leq h_{0} / t \leq 120$, it may be shown that the compression strength due to local buckling, $\sigma_{b}$, around a circular opening is given with reasonable accuracy by the following approximate formula: 


$$
\frac{\sigma_{b}}{f_{y}}=1.0-0.6 \times\left[\left[\frac{h_{o}}{45 t}\right]^{0.5}\left[\frac{f_{y}}{235}\right]^{0.25}-1\right]
$$

It follows that $\sigma_{b} / f_{\mathrm{y}}=1.0$ for $h_{\mathrm{o}} / t<45\left(235 / f_{\mathrm{y}}\right)^{0.25}$.

This formula may also be used for closely spaced openings, in which the same effective slenderness of $\lambda=0.7 h_{O} / t$ around the opening may be used. Therefore, the theoretical ratio $\sigma_{b} / f_{y}$ due to local buckling is independent of the opening spacing.

Table 7 presents a comparison of buckling strength ratios $\sigma_{b} / f_{\mathrm{y}}$ for various $h_{\delta} / t$ ratios and for two strength grades using the approximate equation (21) to the more accurate results obtained from buckling curve to EN 1993-1-4, as noted above.

Table 6 also shows the comparison of equation (21) using the test data with the stress ratio at the failure load of each test given by $\sigma f_{\mathrm{y}}$. This shows that equation (19) is conservative by 10 to $16 \%$ for openings at $100 \mathrm{~mm}$ edge spacing and 5 to $25 \%$ for openings at $50 \mathrm{~mm}$ edge spacing. It is conservative by 31 to $35 \%$ for isolated openings suggesting that the effective slenderness for local buckling could be reduced in this case.

Table $7 \quad$ Maximum normal stress on the radial plane around circular openings limited by local buckling as a function of $h_{d} / t$ and steel grade, $f_{y}$

This value of $\sigma_{b}$ obtained from equation (21) may be used to determine the shear resistance of the perforated section when limited by local buckling. This is presented in Table 8 in terms of the maximum vertical shear stress $\tau_{v}$ that can be resisted by the perforated section with various opening sizes and for two values of $f_{y}$. 
Table 8 Maximum vertical shear stress $\tau_{v}$ at isolated circular openings when limited by local buckling as a function of $h / t$ and steel yield strength, $f_{y}$

\section{Comparison with the method in SCI P355 for hot rolled sections}

The simplified method in this paper may be compared with the method given in $\mathrm{SCl}$ P355 (Lawson and Hicks, 2011) for hot rolled steel sections subject to web-post buckling. In the $\mathrm{SCI}$ method for closely spaced openings, the important parameter is considered to be the horizontal shear stress in the web-post rather than the compression stress around the opening. In this method, the notional effective length of the equivalent web-post strut is given by:

$$
\ell_{w}=0.5\left(h_{\circ}^{2}+s_{o}^{2}\right)^{0.5}
$$

The buckling strength of the web-post at this notional effective length is obtained using buckling curve 'c ' to EN 1993-1-1, and this buckling strength is then treated as being equivalent to the horizontal shear strength of the web-post, $\tau_{\mathrm{H}}$. The method in SCI P355 has been calibrated against full-scale tests on Class 1 and 2 steel and composite beams with circular and elongated web openings and is found to be conservative but reasonably accurate for design purposes.

A comparison of the buckling strength obtained from the method in SCI P355 using the geometric and material data from the tests in this paper is presented in Table 9 and is compared to the horizontal shear stress in the web-post at the failure load of the $\mathrm{C}$ sections. This shows that $\mathrm{SCI}$ P355 is reasonably accurate for the tests on $2 \mathrm{~mm}$ thick 1.4301 steel but is increasingly conservative for the tests using the higher strength LDX grade steel. However, it is found to be un-conservative for the tests on $3 \mathrm{~mm} 1.4301$ thick steel. Therefore, because of this variability of results given by SCI P355 for the tested Class 4 sections, it proposed that the simplified method in this 
paper is more appropriate for the design of circular openings in stainless steel sections subject to high shear.

Table 9 Comparison of the horizontal shear stresses at failure in the tests with predictions to SCI P355 for hot rolled steel sections

\section{Finite Element Analysis of Beams with Circular Web Openings}

In order to compare with the elastic model of normal stresses on a radial plane, a series of finite element analyses was carried out for the test beams using the program LUSAS and linear elastic material properties. The beams were analysed with an axis of symmetry at mid-span, in which the left hand side represents the end support and the right hand side represents the fully fixed mid-span condition.

The principal stress results of the FEA models were determined at the shear force corresponding to the failure load in the tests. This is presented in Figure 13 for the case of openings at $50 \mathrm{~mm}$ spacing in $2 \mathrm{~mm}$ thick sections using lean duplex steel (tests 6 and 8 ). The results are compared in Figure 14 to plots of the stresses around the opening at the failure load. Two curves are presented for the normal stresses on the radial planes from 0 to 180 degrees around the opening:

\footnotetext{
- $\quad$ using equation (6) for the stresses between 10 and $40^{\circ}$ to the vertical

- $\quad$ using equation(15) and for an opening spacing of one third of the diameter, which controls for the stresses between 50 and $70^{\circ}$ to the vertical
}

The stresses are also slightly influenced by overall bending stresses so the results are not symmetric about the horizontal axis $\left(90^{\circ}\right)$. It is shown that the method in this paper method agrees reasonably well with the FEA results for closely spaced openings. 
Figure 13: Principal stresses from the FEA at the failure load for the tests on $2 \mathrm{~mm}$ thick lean duplex steel with openings at $50 \mathrm{~mm}$ spacing (support at right hand side)

Figure 14: Comparison between the principal stresses around the openings from the FEA at the test failure load and normal stresses from the design method for the tests on $2 \mathrm{~mm}$ thick lean duplex steel with openings at $50 \mathrm{~mm}$ spacing

Then the elasto-plastic finite element program ANSYS was used to simulate the nonlinear behaviour due to the precise stress-strain curve for the particular steel type. The interfaces between the support blocks and the $\mathrm{C}$ section were also modelled. The model was based on the centre-line dimensions of the cross-sections. Uzzaman et al (2012) developed finite element models for web crippling behaviour of coldformed steel beams with openings and similar techniques were adopted to developed finite element models for the stainless steel beams with openings.

One-half of the test set-up was modelled using a symmetrical boundary condition at mid-span. Contact surfaces were defined between the support block and the $\mathrm{C}$ section. The plasticity of the material was determined by a mathematical model, known as the incremental plasticity model; the true stress, $\sigma_{\text {true }}$ and plastic true strain, $\varepsilon_{\text {true }}$. The stainless steel sections were modelled using the 4-noded shell element SHELL181. The support blocks were modelled using the eight-noded solid element SOLID45. CONTAT173 and TARGET170 elements were used for modelling contact between the webs and the support blocks.

The effect of different element sizes in the cross-section of the stainless steel section was investigated to provide accurate results. Depending on the size of the section, the finite element mesh sizes ranged from $5 \times 5 \mathrm{~mm}$ (length by width) to $10 \times 10 \mathrm{~mm}$. Nine elements were used around the inside corner radius that forms the bend 
between the flange and web. Three elements were used at the rounded corners between the flange and lip of the section. The number of elements was chosen so that the aspect ratio of the elements was as close to one as possible. Where holes were modelled, finer mesh sizes were used around the web holes.

The nodes of the support and loading blocks were restrained to represent the symmetry condition at mid-span. The interface between the support and loading blocks and the stainless steel section were modelled using the surface-to-surface contact option. The support and loading blocks were the target surface, while the stainless steel section was the contact surface. The two contact surfaces were not allowed to penetrate each other.

The vertical load applied to the sections in the laboratory tests was modelled using displacement control method in which an imposed displacement was applied to the nodes of the top loading block where the vertical load is applied. The top loading block was restrained against all degrees of freedom, except for the translational degree of freedom in the $y$ - direction. The node coupling method was used in the region where the section connected to the support and loading blocks. The nodes were coupled together in all degrees of freedom.

A comparison of the test results $\left(P_{\mathrm{EXP}}\right)$ with the numerical results $\left(P_{\mathrm{FEA}}\right)$ of failure load is shown in Table 10. Load-deflection curves comparing the experimental results and the finite element results for the $2 \mathrm{~mm}$ thick $\mathrm{C}$ sections using lean duplex (1.4162) with openings at $100 \mathrm{~mm}$ spacing are shown in Figure 15. The deflected shape and stress pattern for this test is shown in Figure 16.

It can be seen that good agreement has been achieved between the results for all specimens. The mean value of the $P_{\mathrm{EXP}} / P_{\mathrm{FEA}}$ ratio is 0.99 with the corresponding 
coefficient of variation of 0.11 . A maximum difference of $13 \%$ was observed for the test 6 and all the tests with $100 \mathrm{~mm}$ opening edge distance had a $P_{\text {EXP }} / P_{\mathrm{FEA}}$ ratio less than 1.0. The web crippling failure mode observed from the tests has been also verified by the finite element model.

Table 10 Comparison of failure loads predicted from finite element analysis (FEA) with test results

Figure 15 Comparison of load - displacement curves for lean duplex $2 \mathrm{~mm}$ thick steel with openings at $100 \mathrm{~mm}$ spacing

Figure 16 Buckled shape and stresses $2 \mathrm{~mm}$ thick lean duplex steel with openings at $100 \mathrm{~mm}$ spacing

\section{Approximate Formulae for Shear Resistance of Stainless Steel C Sections with Circular Openings}

By combining equations (9) and (21), it may be shown that for cases controlled by local buckling, in which $h_{\mathrm{o}} / t>45\left(235 / f_{\mathrm{y}}\right)^{0.5}$, the maximum shear stress, $\tau_{\mathrm{v}}$, that may be resisted at the centre-line of widely spaced circular openings is given by the following approximate equation::

$$
\tau_{v}=\left[\frac{h}{4 h_{o}}\right] \cdot\left[1-0.6\left[\left[\frac{h_{o}}{45 t}\right]^{0.5}\left[\frac{f_{y}}{235}\right]^{0.25}-1\right]\right] . f_{\mathrm{y}} \quad \text { for } s>h
$$

For $h_{\mathrm{o}} / t<45\left(235 / f_{\mathrm{y}}\right)^{0.5}$, it is considered that local buckling does not occur around the openings, and so the compression stress around the opening, $\sigma$, can reach $\mathrm{f}_{\mathrm{y}}$. Therefore, the maximum value of $\tau_{v}=0.25\left(h / h_{\circ}\right) f_{\mathrm{y}}$ for widely spaced openings.

For closely spaced openings in which $s<h$, a further reduction factor of $\left(s-h_{\circ}\right) /\left(h-h_{\circ}\right)$ applies to the above formula, as given by the inverse of equation (18). Therefore, for $h_{0} / t>45\left(235 / f_{y}\right)^{0.5}$, the maximum shear stress, $\tau_{v}$, that may be resisted at the centreline of the openings is given by the following approximate equation:: 


$$
\tau_{v}=\left[\frac{h}{4 h_{o}}\right] \cdot\left[\frac{s-h_{o}}{h-h_{o}}\right] \cdot\left[1-0.6\left[\left[\frac{h_{o}}{45 t}\right]^{0.5}\left[\frac{f_{y}}{235}\right]^{0.25}-1\right]\right] . f_{y} \text { for } s<h
$$

Although these equations have been calibrated against tests on higher grade lean duplex steel with $h_{\mathrm{o}} / t=75$ and $\mathrm{f}_{\mathrm{y}}=530 \mathrm{~N} / \mathrm{mm}^{2}$, it is considered that they are valid up to $h_{\mathrm{o}} / t<120\left(235 / f_{\mathrm{y}}\right)^{0.5}$, given the elastic nature of local buckling at higher plate slenderness. The agreement between tests and the simplified theory is shown to be good.

For $h_{\mathrm{o}} / t<45\left(235 / f_{\mathrm{y}}\right)^{0.5}$, it is considered that local buckling of the web-post does not occur. Therefore:

$$
\tau_{v}=\left[\frac{h}{4 h_{o}}\right] \cdot\left[\frac{s-h_{o}}{h-h_{o}}\right] \cdot f_{\mathrm{y}} \quad \text { for } s<h
$$

Further simplifications may be made to obtain even more useable equations for the maximum shear stress at the openings, $\tau_{\mathrm{v}}$, when limited local buckling, as follows:

$$
\begin{array}{ll}
\tau_{v}=\left[\frac{h}{4 h_{o}}\right] \cdot\left[\frac{45 t}{h_{o}}\right]^{0.5}\left[\frac{235}{f_{y}}\right]^{0.25} \cdot f_{\mathrm{y}} & \text { for } s>h \\
\tau_{\mathrm{v}}=\left[\frac{h}{4 h_{o}}\right] \cdot\left[\frac{s-h_{o}}{h-h_{o}}\right] \cdot\left[\frac{45 t}{h_{o}}\right]^{0.5}\left[\frac{235}{f_{y}}\right]^{0.25} \cdot f_{\mathrm{y}} & \text { for } s<h
\end{array}
$$

Equations (26 and (27) are more conservative than equations (24) and (25) in the range of $h_{\mathrm{o}} / \mathrm{t}$ of 60 to 90 and are valid up to $h_{\mathrm{o}} / t<100\left(235 / f_{\mathrm{y}}\right)^{0.5}$.

\section{Conclusions}

The tests on pairs of stainless steel C section beams with widely spaced $150 \mathrm{~mm}$ diameter openings failed by Vierendeel bending and local buckling at an angle of approximately $25^{\circ}$ to the vertical. The tests on beams with closely spaced openings generally failed by web-post buckling. The tests on beams with openings at $100 \mathrm{~mm}$ 
edge spacing, the failure load was $25 \%$ less than for beams with widely spaced openings, and for openings at $50 \mathrm{~mm}$ spacing, the failure load was $34 \%$ less.

Increasing the steel thickness from 2 to $3 \mathrm{~mm}$, failure load increased by 91 to $113 \%$. Using higher strength lean duplex (1.4162) steel, the failure load shear was 41 to $58 \%$ higher than the same tests using austenitic (1.4301) steel.

A method of calculating the local stresses around the circular openings is presented. At the failure load of the tests, the ratio of the normal stresses on the radial plane around the openings to the proof strength of the steel was in the range of 0.71 to 1.21 , the lower values corresponding to the effects of local buckling of the web-post for closely spaced openings. The compression or tension stresses around an opening may be determined with reasonable accuracy by the formula:

$$
\left.\sigma=\frac{V_{E d}(1.5 \sin 2 \theta)}{h t\left[1-\left(h_{O} / h\right) \cos \theta\right]^{2}}, \text { where } \theta=\cos ^{-1}\left[0.25\left(h_{O} / h\right)+0.72\right)\right]
$$

When the centre-centre spacing of the openings, $s$, is less than the section depth, $h$, the failure mode is dependent on the stresses in the web-post between the openings. The highest local stresses around the opening occur at about $65^{\circ}$ to the vertical, and may be determined with reasonable accuracy by the formula:

$$
\left.\sigma=\frac{V_{E d^{1.5 \sin 2 \theta}}}{h t\left[1-\left(h_{O} / s\right) \sin \theta\right]^{2}}, \text { where } \theta=\sin ^{-1}\left[0.25\left(h_{O} / s\right)+0.72\right)\right]
$$

For $h_{0} / t>45\left(235 / f_{y}\right)^{0.5}$, the compression stress, $\sigma$ is limited to the local buckling strength, $\sigma_{b}$, which is determined from the following approximate formula:

$$
\frac{\sigma_{b}}{f_{y}}=1.0-0.6\left[\left[\frac{h_{o}}{45 t}\right]^{0.5}\left[\frac{f_{y}}{235}\right]^{0.25}-1\right] \quad<1.0
$$


It may be shown that the maximum shear stress, $\tau_{v}$, acting at the centre-line of circular openings is given by the following approximate equations, depending on the spacing of the openings:

$$
\begin{array}{ll}
\tau_{v}=\left[\frac{h}{4 h_{o}}\right] \cdot \sigma_{b} & \text { for } s>h \\
\tau_{v}=\left[\frac{h}{4 h_{o}}\right] \cdot\left[\frac{s-h_{o}}{h-h_{o}}\right] \cdot \sigma_{b} . & \text { for } s<h
\end{array}
$$

The agreement between tests and this simplified theory is shown to be good. These formula may be used for stainless steel sections with web openings up to $h_{\mathrm{o}} / t<120$ $\left(235 / f_{\mathrm{y}}\right)^{0.5}$. More work is required to calibrate the results against tests for cold formed steel sections in which the buckling curve is obtained from EN 1993-1-1. 


\section{References}

American Institute of Steel Construction, Structural Stainless Steel: Steel Design Guide 27, Published with the Steel Construction Institute (author Baddoo N.)

Baddoo, N.R. Stainless Steel in Construction: A review of research, applications, challenges and opportunities, Journal of Constructional Steel Research, 2008, 64, 11, pp 1199-1206

Bock $M$ and Real E, Strength curves for web crippling design of cold formed stainless steel hat sections, Thin Walled Structures, 85, 2014 pp $93-105$

BS EN 10088-4:2009 Stainless steels. Technical delivery conditions for sheet/plate and strip of corrosion resisting steels for construction purposes.

BS EN 1993-1-1, Eurocode 3: Design of Steel Structures - Part 1.1: General Rules and Rules for Buildings. 2005.

BS EN 1993-1-3 Eurocode 3: Design of Steel Structures- General RulesSupplementary Rules for Cold formed Members and Sheeting, 2006

BS EN 1993-1-4 Eurocode 3: Design of Steel Structures- General RulesSupplementary Rules for Stainless Steel, 2006

BS EN 1994-1-1 Eurocode 4: Design of Composite Steel and Concrete StructuresGeneral Rules and Rules for Buildings, 2005

Darwin D, Design of Steel and Composite Beams with Web Openings, Steel Design Guide Series 2, American Institute of Steel Construction, 1990

Eurolnox/ The Steel Construction Institute, Design Manual for Structural Stainless Steel. Third Edition.- www.steel-stainless.org/designmanual, 2006

\section{European Commission Steel Research}

Large Web Openings for Service Integration in Composite Floors, 2006, EUR 2i345 (available for download at http://bookshop.europa.eu)

Gardner L., Talja A. ,and Baddoo N R. Structural design of high-strength austenitic stainless steel. Thin Walled Structures, 2006: 44(5): pp 517-28.

Gardner L. and Theofanous M. Discrete and continuous treatment of local buckling in stainless steel elements. Journal Constructional Steel Research, 2008: 64(11): pp 1207-16.

Huang $Y$ and Young B, Structural Performance of Cold Formed Lean Duplex Stainless Steel Columns, Thin Walled Structures, 83, 2014 p $59-69$

Lawson $\mathrm{R} M$ Design of Openings in the Webs of Composite Beams SCI/CIRIA Publication P068, 1987, London

Lawson RM and Hicks SJ Design of Composite Beams with Large Web Openings, SCI Publication, P 355, 2011, The Steel Construction Institute 
Moen CD and Schafer BW. Direct Strength Method for Design of Cold-formed Steel Columns with Holes. American Society of Civil Engineers. Journal Structural Engineering 2011, 137(5) p 559-570

Moen CD, Schafer BW. Direct Strength design of cold-formed steel members with perforations. Washington, DC: American Iron and Steel Institute; 2009.

Moen CD, Schafer BW. Direct Strength Method for Design of Cold-Formed Steel Columns with Holes. Journal of Structural Engineering 2011; 137(5)559-570.

Moen CD, Schudlich A, von der Heyden A. Experiments on Cold-formed Steel Joists with Unstiffened Web Holes. Journal of Structural Engineering 2013; 139(ColdFormed Steel Structures):695-704.

Moen CD, Schafer BW. Elastic Buckling of Thin plates with Holes in Compression or Bending. Thin-Walled Structures 2009; 47(12):1597-1607.

Outokumpu Data sheet (2009). LDX 2101(R), 2304, 2205-Duplex steels for structural hollow sections http://www.outokumpu.com/42329.epibrw.

Real E, Arrayago I, Mirambell E and Westeel R, Comparative Study of Analytical Expressions for the Modelling of Stainless Steel Behaviour. Thin Walled Structures, 83, 2014 p2 - 11

Redwood RJ, Design of Beams with Web Holes, Canadian Steel Industries Construction Council, 1973

Sahmel P, The design, construction and approximate calculation of welded transverse beams and torsion bars having large web openings (in German), Schweissen and Schneiden, 1969, 21 (3) , p116- 122

Saliba N, Read E and Gardner L , Shear design recommendations for stainless steel plate girders, Engineering Structures 59, 2014, p $220-228$

Theofanous M and Gardner L., Experimental and Numerical Studies of Lean Duplex Stainless Steel Beams, Journal of Constructional Steel Research, 2010, 66, pp 816825

Theofanous, M. and Gardner, L. Testing and numerical modelling of lean duplex stainless steel hollow section columns. Engineering Structures. 2009, 31, 12, p 30473058

Uzzaman, A. Lim J.B.P, Nash D., Rhodes J.,. Young B, Web crippling behaviour of cold-formed steel channel sections with offset web holes subjected to interior-twoflange loading, Thin-Walled Structures, 50 (2012) 76-86.

Ward J K, Design of Composite and Non-Composite Cellular Beams, SCI P100, 1990, The Steel Construction Institute 


\section{Acknowledgements}

The University of Surrey thanks the Outokumpu Stainless Steel Research Foundation for supporting this research and for providing the test specimens with web openings.

Nancy Baddoo of The Steel Construction Institute provided useful background information on stainless steel research.

The first part of the test work was carried out by Masters student, $K$ Shanmugalingham at the University of Surrey, and tests were performed by Chief Technician, Peter Haynes, who are thanked for their help. 


\section{List of Tables}

1. Test series and failure loads and failure modes

2. Tensile test results for the steels used in the tests

3. Shear stresses and load ratios at the failure loads in the tests

4. Maximum compression stress at edge of opening as a multiple of the vertical shear stress at the opening

5 Maximum compression stress around the opening as a function of the vertical shear stress at the opening and the horizontal shear stress in the web-post

6 Maximum normal stress, $\sigma$ on the radial plane calculated at the test failure loads

7 Maximum normal stress around circular openings limited by local buckling as a function of $h_{o} / t$ and steel grade, $f_{y}$

8 Maximum shear stress $\tau_{v}$ at circular openings as a function of $h_{0} / t$ and steel strength, $f_{y}$

9 Comparison of the horizontal shear stresses in the web-post at failure in the tests with predictions to SCI P355 for hot rolled steel sections

10 Comparison of failure loads predicted from finite element analysis (FEA) with experiment results

\section{List of Figures}

1. Various forms of web openings in stainless steel beams

2. Lateral torsional buckling curves for stainless steel and carbon steel to Eurocode 3 (Baddoo)

3. Test arrangement for a pair of $\mathrm{C}$ sections with a central point load (Test 1 shown)

4. Details of web opening positions in the tests

5. Mode of failure by Vierendee/ bending around the opening causing local buckling - Test 1 after test and placed on the lab floor

6. Mode of failure by web-post buckling with closely spaced openings- Test 2 with $50 \mathrm{~mm}$ opening spacing

7. Mode of failure by local buckling failure around the bolts at the load point Test 3 with $100 \mathrm{~mm}$ opening spacing

8. Load-displacement for test 2 using $3 \mathrm{~mm}$ thick steel and closely spaced openings

9. Local stresses measured in the test using $3 \mathrm{~mm}$ thick 1.4301 steel with openings at $100 \mathrm{~mm}$ spacing

(a) Stresses around the openings

(b) Location of strain gauges in test 2

10. Stress-strain curve for $2 \mathrm{~mm}$ thick lean duplex stainless steel trade name LDX $2101^{(\mathrm{R})}$ )

11. Equilibrium of forces acting on radial plane $\theta$, when $\theta \leq \tan ^{-1}(\mathrm{~s} / \mathrm{d})$

12. Equilibrium of forces acting on radial plane $\theta$, when $\theta>\tan ^{-1}(\mathrm{~s} / \mathrm{d})$

13. Principal stresses from the FEA at the failure load for the tests on LDX 2101x $2 \mathrm{~mm}$ thick steel with openings at $50 \mathrm{~mm}$ spacing (support at right hand side)

14. Comparison between the principal stresses around the openings from the FEA at the test failure load and normal stresses from the design method for the tests on $1.4162 \times 2 \mathrm{~mm}$ thick steel with openings at $50 \mathrm{~mm}$ spacing

15. Comparison load - displacement curves for lean duplex $2 \mathrm{~mm}$ thick steel with openings at $100 \mathrm{~mm}$ spacing

16. Buckled shape and stresses $2 \mathrm{~mm}$ thick lean duplex steel with openings at $100 \mathrm{~mm}$ spacing 
Table 1 Test series, failure loads and failure modes

\begin{tabular}{|c|c|c|c|c|c|}
\hline $\begin{array}{l}\text { Test } \\
\text { No. }\end{array}$ & $\begin{array}{l}\text { Stainless } \\
\text { steel type/ } \\
\text { thickness }\end{array}$ & $\begin{array}{l}\text { Opening } \\
\text { edge- } \\
\text { edge } \\
\text { spacing }\end{array}$ & $\begin{array}{c}\text { Failure } \\
\text { load, kN } \\
\text { for } 2 \\
\text { beams }\end{array}$ & $\begin{array}{c}\text { Failure } \\
\text { shear force, } \\
\text { kN per } \\
\text { beam }\end{array}$ & Mode of failure in test \\
\hline $1 \& 9$ & \multirow{3}{*}{$\begin{array}{c}\text { Austenitic } \\
1.4301 / \\
2 \mathrm{~mm}\end{array}$} & $250 \mathrm{~mm}$ & $58 / 61.5$ & $14.5 / 15.4$ & $\begin{array}{l}\text { Vierendeel bending with local } \\
\text { buckling at the openings }\end{array}$ \\
\hline 3 & & $100 \mathrm{~mm}$ & 44.5 & 11.1 & $\begin{array}{l}\text { Buckling of web and top flange } \\
\text { at load application point }\end{array}$ \\
\hline 7 & & $50 \mathrm{~mm}$ & 39.4 & 9.9 & $\begin{array}{l}\text { Horizontal shear causing web- } \\
\text { post buckling }\end{array}$ \\
\hline 5 & \multirow{2}{*}{$\begin{array}{c}\text { Austentic } \\
1.4301 / \\
3 \mathrm{~mm}\end{array}$} & $100 \mathrm{~mm}$ & 86.0 & 21.5 & $\begin{array}{l}\text { Horizontal shear causing web- } \\
\text { post buckling }\end{array}$ \\
\hline 2 & & $50 \mathrm{~mm}$ & 84.0 & 21.0 & $\begin{array}{l}\text { Horizontal shear with slight } \\
\text { local buckling of web-post }\end{array}$ \\
\hline 4 & \multirow{2}{*}{$\begin{array}{c}\text { Lean Duplex } \\
1.4162 / \\
2 \mathrm{~mm}\end{array}$} & $100 \mathrm{~mm}$ & 71.5 & 17.9 & $\begin{array}{l}\text { Buckling of web and top flange } \\
\text { at load application point }\end{array}$ \\
\hline $6 \& 8$ & & $50 \mathrm{~mm}$ & $54.2 / 55.4$ & $13.5 / 13.8$ & $\begin{array}{l}\text { Horizontal shear causing web- } \\
\text { post buckling }\end{array}$ \\
\hline
\end{tabular}

Table 2 Tensile test results for the stainless steels used in the tests

\begin{tabular}{|c|c|c|c|c|}
\hline $\begin{array}{c}\text { Steel } \\
\text { type }\end{array}$ & $\begin{array}{c}\text { Thick- } \\
\text { ness }\end{array}$ & $\begin{array}{c}\text { Proof } \\
\text { Strength at } \\
\mathbf{0 . 2 \%} \text { strain } \\
\mathbf{N} / \mathbf{m m}^{2}\end{array}$ & $\begin{array}{c}\text { Strength } \\
\text { at 6\% } \\
\text { strain } \\
\mathbf{N} / \mathbf{m m}^{2}\end{array}$ & $\begin{array}{c}\text { Ultimate } \\
\text { Strength } \\
\mathbf{N} / \mathbf{m m}^{2}\end{array}$ \\
\hline $\begin{array}{c}\text { Austenitic } \\
\mathbf{1 . 4 3 0 1}\end{array}$ & $2 \mathrm{~mm}$ & 285 & 400 & 650 \\
\hline $\begin{array}{c}\text { Austenitic } \\
\mathbf{1 . 4 3 0 1}\end{array}$ & $3 \mathrm{~mm}$ & 310 & 450 & 680 \\
\hline $\begin{array}{c}\text { Lean duplex } \\
\mathbf{1 . 4 1 6 2}\end{array}$ & $2 \mathrm{~mm}$ & 530 & 700 & 790 \\
\hline
\end{tabular}


Table 3 Shear stresses and load ratios at the failure loads in the tests

\begin{tabular}{|c|c|c|c|c|c|c|c|}
\hline \multirow{2}{*}{$\begin{array}{l}\text { Steel type } \\
\text { and } \\
\text { thickness }\end{array}$} & \multirow{2}{*}{$\begin{array}{l}\text { Opening } \\
\text { edge } \\
\text { spacing } \\
(\mathrm{mm})\end{array}$} & \multirow{2}{*}{$\begin{array}{l}\text { Vertical } \\
\text { shear } \\
\text { stress at } \\
\text { opening } \\
\left(\mathrm{N} / \mathrm{mm}^{2}\right)\end{array}$} & \multirow{2}{*}{$\begin{array}{l}\text { Horizontal } \\
\text { shear } \\
\text { stress in } \\
\text { web-post } \\
\left(\mathrm{N} / \mathrm{mm}^{2}\right)\end{array}$} & \multicolumn{4}{|c|}{$\begin{array}{l}\text { Load ratios in bending and shear at the } \\
\text { critical opening at the test failure load }\end{array}$} \\
\hline & & & & $M / M_{e l, R d}$ & $V / V_{V, R d}$ & $V_{h} / V_{h, R d}$ & $V / V_{\text {vier, } R d}$ \\
\hline \multirow{3}{*}{$\begin{array}{c}\text { Austenitic } \\
1.4301 / \\
2 \mathrm{~mm}\end{array}$} & 250 & $125 / 133$ & $59 / 63$ & $0.53 / 0.56$ & $0.76 / 0.80$ & $0.36 / 0.38$ & $1.17 / 1.24$ \\
\hline & 100 & 95 & 72 & 0.48 & 0.58 & 0.43 & 0.84 \\
\hline & 50 & 85 & 102 & 0.36 & 0.56 & 0.62 & 0.66 \\
\hline \multirow{2}{*}{$\begin{array}{c}\text { Austenitic } \\
1.4301 / \\
3 \mathrm{~mm}\end{array}$} & 100 & 126 & 92 & 0.63 & 0.70 & 0.52 & 1.27 \\
\hline & 50 & 123 & 145 & 0.51 & 0.69 & 0.81 & 1.01 \\
\hline \multirow{2}{*}{$\begin{array}{c}\text { Lean Duplex } \\
1.4162 / \\
2 \mathrm{~mm} \\
\end{array}$} & 100 & 154 & 116 & 0.37 & 0.50 & 0.38 & 0.65 \\
\hline & 50 & $116 / 119$ & $140 / 143$ & $0.23 / 0.27$ & $0.38 / 0.39$ & $0.45 / 0.46$ & $0.44 / 0.45$ \\
\hline \multicolumn{8}{|l|}{$\begin{array}{ll}\boldsymbol{M} & \text { Bendi } \\
\boldsymbol{M}_{\text {el, } \boldsymbol{R d}} & \text { Elastic } \\
\boldsymbol{V} & \text { Shear } \\
\boldsymbol{V}_{\boldsymbol{V}, \boldsymbol{R} \boldsymbol{d}} & \text { Vertic } \\
\boldsymbol{V}_{\boldsymbol{h}} & \text { Horizo } \\
\boldsymbol{V}_{\boldsymbol{h}, \boldsymbol{R d}} & \text { Horiz } \\
\boldsymbol{V}_{\boldsymbol{v i e r}, \boldsymbol{R} \boldsymbol{d}} & \text { Vierer }\end{array}$} \\
\hline
\end{tabular}

Table 4 Maximum compression stress at edge of opening as a multiple of the vertical shear stress at the opening.

\begin{tabular}{|c|c|c|c|}
\hline$h_{d} / h$ & $\theta$ & $\sigma$ & For $\sigma=\mathrm{f}_{\mathrm{y}, ~} \tau_{\mathrm{v}}=$ \\
\hline 0.5 & $32^{\circ}$ & $2.03 \tau_{\mathrm{v}}$ & $0.85 \tau_{\mathrm{v}, \mathrm{Rd}}$ \\
\hline 0.6 & $29^{\circ}$ & $2.25 \tau_{\mathrm{v}}$ & $0.77 \tau_{\mathrm{v}, \mathrm{Rd}}$ \\
\hline 0.7 & $26^{\circ}$ & $2.58 \tau_{\mathrm{v}}$ & $0.67 \tau_{\mathrm{v}, \mathrm{Rd}}$ \\
\hline 0.8 & $23^{\circ}$ & $3.17 \tau_{\mathrm{v}}$ & $0.55 \tau_{\mathrm{v}, \mathrm{Rd}}$ \\
\hline
\end{tabular}

$\tau_{v}$ is the vertical shear stress at the centre of opening

$\sigma$ is the normal stress around the opening 
Table 5 Maximum compression stress around the opening as a function of the vertical shear stress at the opening and the horizontal shear stress in the web-post

\begin{tabular}{|c|c|c|c|c|}
\hline \multirow{2}{*}{$h / h$} & $s / h_{\circ}=2.0$ & $=1.7$ & $=1.5$ & $=1.3$ \\
\cline { 2 - 5 } & $\theta=58^{\circ}$ & $=60^{\circ}$ & $=62^{\circ}$ & $=65^{\circ}$ \\
\hline 0.5 & $2.03 \tau_{\mathrm{v}}$ & $2.22 \tau_{\mathrm{H}}$ & $2.45 \tau_{\mathrm{H}}$ & $2.88 \tau_{\mathrm{H}}$ \\
\hline 0.6 & $1.62 \tau_{\mathrm{v}}$ & $2.16 \tau_{\mathrm{v}}$ & $2.45 \tau_{\mathrm{H}}$ & $2.88 \tau_{\mathrm{H}}$ \\
\hline 0.7 & $1.22 \tau_{\mathrm{v}}$ & $1.62 \tau_{\mathrm{v}}$ & $2.21 \tau_{\mathrm{v}}$ & $2.88 \tau_{\mathrm{H}}$ \\
\hline 0.8 & $0.81 \tau_{\mathrm{v}}$ & $1.08 \tau_{\mathrm{v}}$ & $1.47 \tau_{\mathrm{v}}$ & $2.50 \tau_{\mathrm{v}}$ \\
\hline
\end{tabular}

$\tau_{V}$ is the vertical shear stress at the centre of the opening

$\tau_{H}$ is the horizontal shear stress in the web-post, which is shown when $\tau_{H}>\tau_{V}$

Table 6 Maximum normal stress, $\sigma$ on the critical radial plane calculated for the test failure loads

\begin{tabular}{|c|c|c|c|c|c|}
\hline $\begin{array}{l}\text { Steel type } \\
\text { and } \\
\text { thickness }\end{array}$ & $\begin{array}{l}\text { Opening } \\
\text { edge } \\
\text { spacing } \\
(\mathrm{mm})\end{array}$ & $\begin{array}{c}\text { Failure } \\
\text { shear force } \\
\text { per C } \\
\text { section } \\
\text { (kN) }\end{array}$ & $\begin{array}{c}\text { Local normal } \\
\text { stress, } \sigma \\
\text { around openings } \\
\left(\mathrm{N} / \mathrm{mm}^{2}\right)\end{array}$ & $\begin{array}{c}\text { Ratio of } \\
\text { normal stress } \\
\text { to steel proof } \\
\text { strength, } \\
\sigma / f_{y}\end{array}$ & $\begin{array}{c}\text { Ratio of buckling } \\
\text { strength } \sigma_{b} \text { from } \\
\text { Eqn (21) to steel } \\
\text { proof strength, } \\
\sigma_{b} / f_{y}\end{array}$ \\
\hline \multirow{3}{*}{$\begin{array}{c}1.4301 / \\
2 \mathrm{~mm}\end{array}$} & 250 & $14.5 / 15.4$ & $322 / 341\left(\theta=26^{\circ}\right)$ & $1.13 / 1.20$ & \multirow{3}{*}{0.79} \\
\hline & 100 & 11.1 & $246\left(\theta=26^{\circ}\right)$ & 0.86 & \\
\hline & 50 & 9.9 & $266\left(\theta=65^{\circ}\right)$ & 0.93 & \\
\hline \multirow{2}{*}{$\begin{array}{c}1.4301 / \\
3 \mathrm{~mm}\end{array}$} & 100 & 21.5 & $320\left(\theta=26^{\circ}\right)$ & 1.03 & \multirow{2}{*}{0.92} \\
\hline & 50 & 21.0 & $378\left(\theta=65^{\circ}\right)$ & 1.22 & \\
\hline \multirow{2}{*}{$\begin{array}{c}1.4162 / \\
2 \mathrm{~mm}\end{array}$} & 100 & 17.9 & $409\left(\theta=26^{\circ}\right)$ & 0.77 & \multirow{2}{*}{0.65} \\
\hline & 50 & $13.5 / 13.8$ & $364 / 372\left(\theta=65^{\circ}\right)$ & $0.69 / 0.70$ & \\
\hline
\end{tabular}

$\boldsymbol{\sigma} \quad$ Normal stress on radial plane around opening at the failure load-see theory

$\theta \quad$ Angle of maximum stress to the vertical

$\boldsymbol{f}_{y} \quad$ Yield strength (proof strength) of steel -see Table 2

$\sigma_{b} \quad$ Buckling strength around opening using the method for class 4 webs 
Table $7 \quad$ Maximum normal stress on the radial plane around circular openings limited by local buckling as a function of $h_{\mathrm{o}} / \mathrm{t}$ and steel grade, $f_{\mathrm{y}}$

\begin{tabular}{|c|c|c|c|c|c|c|}
\hline \multirow{2}{*}{$\mathrm{h}_{\mathrm{o}} / \mathrm{t}$} & \multicolumn{3}{|c|}{$\mathrm{f}_{\mathrm{y}}=280 \mathrm{~N} / \mathrm{mm}^{2}$} & \multicolumn{3}{c|}{$\mathrm{f}_{\mathrm{y}}=350 \mathrm{~N} / \mathrm{mm}^{2}$} \\
\cline { 2 - 7 } & $\bar{\lambda}=$ & $\begin{array}{c}\sigma_{\mathrm{b}} / \mathrm{f}_{\mathrm{y}} \\
\text { to EC3-1-4 }\end{array}$ & $\begin{array}{c}\sigma_{\mathrm{b}} / \mathrm{f}_{\mathrm{y}} \\
\text { to Eqn }(21)\end{array}$ & $\bar{\lambda}=$ & $\begin{array}{c}\sigma_{\mathrm{b}} / \mathrm{f}_{\mathrm{y}} \\
\text { to EC3-1-4 }\end{array}$ & $\begin{array}{c}\sigma_{\mathrm{b}} / \mathrm{f}_{\mathrm{y}} \\
\text { to Eqn (21) }\end{array}$ \\
\hline 40 & 0.33 & 1.0 & 1.0 & 0.37 & 1.0 & 0.97 \\
50 & 0.42 & 0.99 & 0.94 & 0.46 & 0.94 & 0.90 \\
60 & 0.50 & 0.94 & 0.88 & 0.56 & 0.90 & 0.83 \\
70 & 0.58 & 0.88 & 0.82 & 0.65 & 0.83 & 0.77 \\
80 & 0.66 & 0.83 & 0.76 & 0.74 & 0.76 & 0.72 \\
90 & 0.75 & 0.76 & 0.71 & 0.84 & 0.70 & 0.66 \\
100 & 0.83 & 0.70 & 0.66 & 0.93 & 0.63 & 0.61 \\
120 & 1.00 & 0.58 & 0.57 & 1.12 & 0.51 & 0.51 \\
\hline
\end{tabular}

$\sigma=\sigma_{\mathrm{b}}$ when local buckling occurs

Table 8 Maximum vertical shear stress $\tau_{v}$ at isolated circular openings when limited by local buckling as a function of $h d t$ and steel yield strength, $f_{y}$

\begin{tabular}{|c|c|c|c|c|c|c|}
\hline \multirow{2}{*}{$h_{d} / t$} & \multicolumn{3}{|c|}{$\mathrm{f}_{\mathrm{y}}=280 \mathrm{~N} / \mathrm{mm}^{2}$} & \multicolumn{3}{c|}{$\mathrm{f}_{\mathrm{y}}=350 \mathrm{~N} / \mathrm{mm}^{2}$} \\
\cline { 2 - 7 } & $h_{\mathrm{o}} / h=0.6$ & $h / h=0.7$ & $h_{o} / h=0.8$ & $h_{d} / h=0.6$ & $h_{d} / h=0.7$ & $h_{d} / h=0.8$ \\
\hline 40 & $0.44 \mathrm{f}_{\mathrm{y}}$ & $0.38 \mathrm{f}_{\mathrm{y}}$ & $0.31 \mathrm{f}_{\mathrm{y}}$ & $0.44 \mathrm{f}_{\mathrm{y}}$ & $0.38 \mathrm{f}_{\mathrm{y}}$ & $0.31 \mathrm{f}_{\mathrm{y}}$ \\
60 & $0.41 \mathrm{f}_{\mathrm{y}}$ & $0.35 \mathrm{f}_{\mathrm{y}}$ & $0.29 \mathrm{f}_{\mathrm{y}}$ & $0.40 \mathrm{f}_{\mathrm{y}}$ & $0.34 \mathrm{f}_{\mathrm{y}}$ & $0.28 \mathrm{f}_{\mathrm{y}}$ \\
80 & $0.36 \mathrm{f}_{\mathrm{y}}$ & $0.31 \mathrm{f}_{\mathrm{y}}$ & $0.25 \mathrm{f}_{\mathrm{y}}$ & $0.33 \mathrm{f}_{\mathrm{y}}$ & $0.29 \mathrm{f}_{\mathrm{y}}$ & $0.23 \mathrm{f}_{\mathrm{y}}$ \\
100 & $0.31 \mathrm{f}_{\mathrm{y}}$ & $0.26 \mathrm{f}_{\mathrm{y}}$ & $0.22 \mathrm{f}_{\mathrm{y}}$ & $0.28 \mathrm{f}_{\mathrm{y}}$ & $0.24 \mathrm{f}_{\mathrm{y}}$ & $0.19 \mathrm{f}_{\mathrm{y}}$ \\
120 & $0.25 \mathrm{f}_{\mathrm{y}}$ & $0.22 \mathrm{f}_{\mathrm{y}}$ & $0.18 \mathrm{f}_{\mathrm{y}}$ & $0.22 \mathrm{f}_{\mathrm{y}}$ & $0.19 \mathrm{f}_{\mathrm{y}}$ & $0.16 \mathrm{f}_{\mathrm{y}}$ \\
\hline
\end{tabular}


Table 9 Comparison of the horizontal shear stresses in the web-post at failure in the tests with predictions to SCI P355 for hot rolled steel sections

\begin{tabular}{|c|c|c|c|c|}
\hline $\begin{array}{l}\text { Steel type } \\
\text { and } \\
\text { thickness }\end{array}$ & $\begin{array}{l}\text { Opening } \\
\text { edge } \\
\text { spacing } \\
(\mathrm{mm})\end{array}$ & $\begin{array}{l}\text { Horizontal } \\
\text { shear stress } \\
\text { in web post } \\
\text { at failure } \\
\left(\mathrm{N} / \mathrm{mm}^{2}\right)\end{array}$ & $\begin{array}{l}\text { Max. horizontal } \\
\text { shear stress for } \\
\text { strut buckling to } \\
\text { SCI P355 } \\
\left(\mathrm{N} / \mathrm{mm}^{2}\right)\end{array}$ & $\begin{array}{l}\text { Max. horizontal } \\
\text { shear stress using } \\
\text { the method in this } \\
\text { paper (using } \sigma_{b} \text { to } \\
\text { Eqn (21) ) }\left(\mathrm{N} / \mathrm{mm}^{2}\right)\end{array}$ \\
\hline \multirow{2}{*}{$\begin{array}{c}1.4301 / \\
2 \mathrm{~mm}\end{array}$} & 100 & 72 & 71 & 64 \\
\hline & 50 & 102 & 86 & 86 \\
\hline \multirow{2}{*}{$\begin{array}{c}1.4301 / \\
3 \mathrm{~mm}\end{array}$} & 100 & 92 & 133 & 77 \\
\hline & 50 & 145 & 164 & 107 \\
\hline \multirow{2}{*}{$\begin{array}{c}1.4162 / \\
2 \mathrm{~mm}\end{array}$} & 100 & 116 & 70 & 95 \\
\hline & 50 & $140 / 143$ & 90 & 129 \\
\hline
\end{tabular}

Table 10 Comparison of failure loads predicted from finite element analysis (FEA) with test results

\begin{tabular}{|c|c|c|c|c|c|c|}
\hline $\begin{array}{c}\text { Test } \\
\text { number }\end{array}$ & $\begin{array}{l}\text { Stainless } \\
\text { Steel type }\end{array}$ & $\begin{array}{l}\text { Thickness } \\
(\mathrm{mm})\end{array}$ & $\begin{array}{c}\text { Opening } \\
\text { spacing } \\
(\mathrm{mm})\end{array}$ & $\begin{array}{c}\text { Test } \\
\text { failure load, } \\
P_{\text {EXP }} \\
(\mathrm{kN}) \\
\end{array}$ & $\begin{array}{c}\text { FEA } \\
\text { failure load, } \\
\text { PFEA } \\
(\mathrm{kN}) \\
\end{array}$ & $\begin{array}{c}\text { Ratio of } \\
\text { Test/ FEA } \\
\text { failure load, } \\
P_{\text {EXP }} / P_{\text {FEA }} \\
\end{array}$ \\
\hline $1 / 9$ & 1.4301 & 2 & 250 & $58 / 61.5$ & 53.1 & $1.09 / 1.15$ \\
\hline 3 & 1.4301 & 2 & 100 & 44.5 & 52.7 & 0.86 \\
\hline 2 & 1.4301 & 3 & 50 & 84 & 82.4 & 1.02 \\
\hline 5 & 1.4301 & 3 & 100 & 86 & 98.3 & 0.87 \\
\hline 4 & 1.4162 & 2 & 100 & 71.5 & 74.9 & 0.95 \\
\hline \multirow[t]{3}{*}{$6 / 8$} & 1.4162 & 2 & 50 & $54.2 / 55.4$ & 47.5 & $1.14 / 1.16$ \\
\hline & & & & & Mean & 0.99 \\
\hline & & & & & STD & 0.11 \\
\hline
\end{tabular}




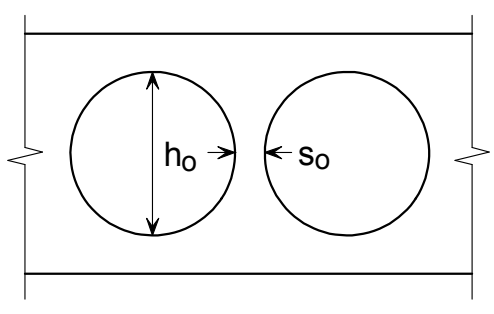

(a) Circular openings

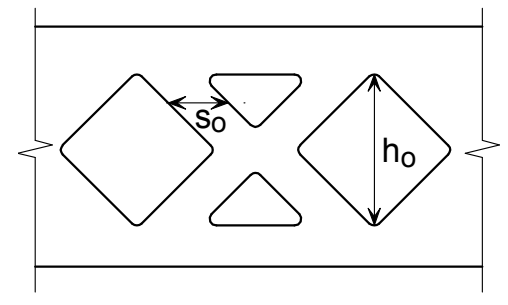

(c) Diamond openings

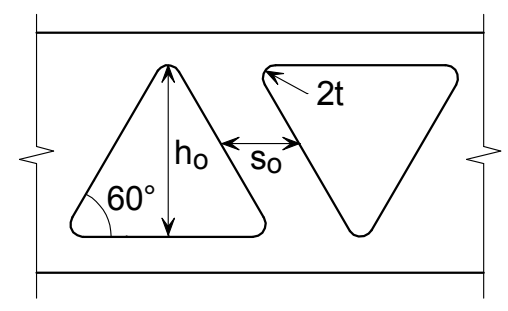

(b) Triangular openings

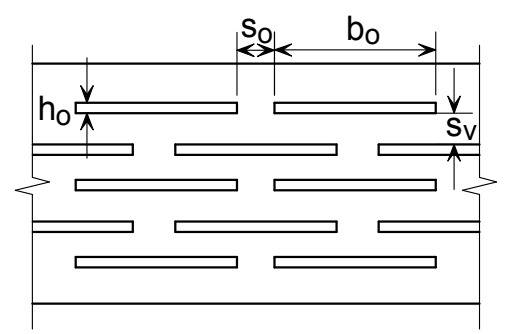

(d) Multiple slots

Figure 1 Various forms of web openings in stainless steel beams

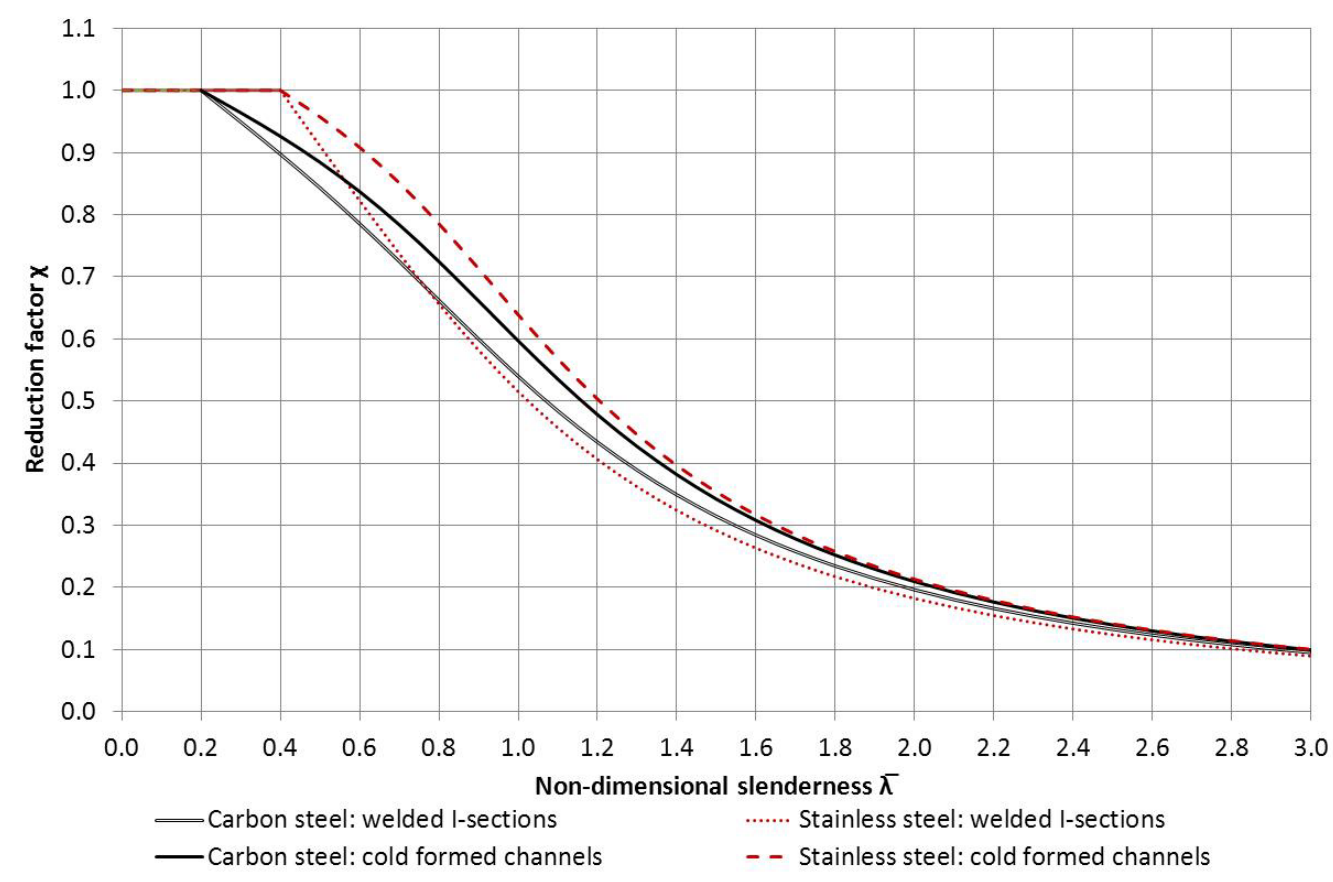

Figure 2 Lateral torsional buckling curves for stainless steel and carbon steel to Eurocode 3 


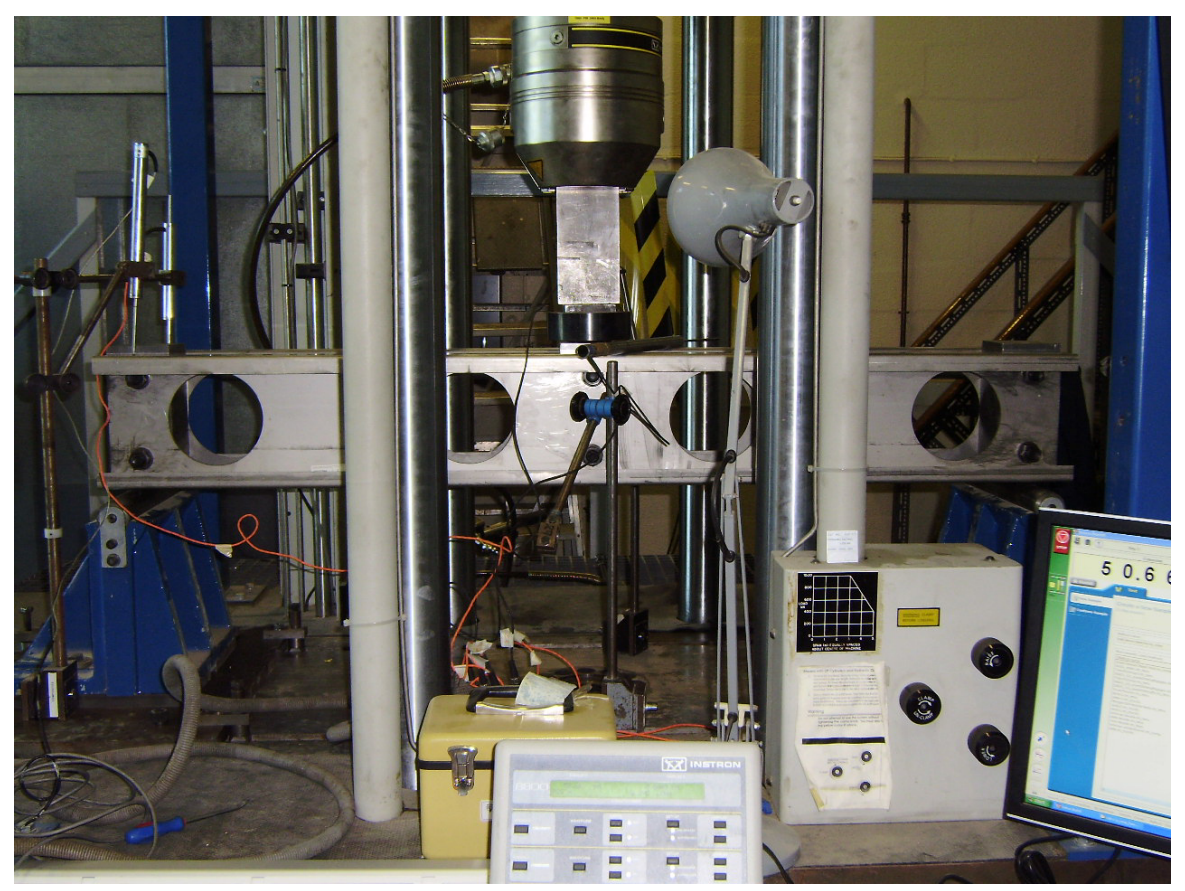

Figure 3 Test arrangement for a pair of $C$ sections with a central point load (Test 1 shown)
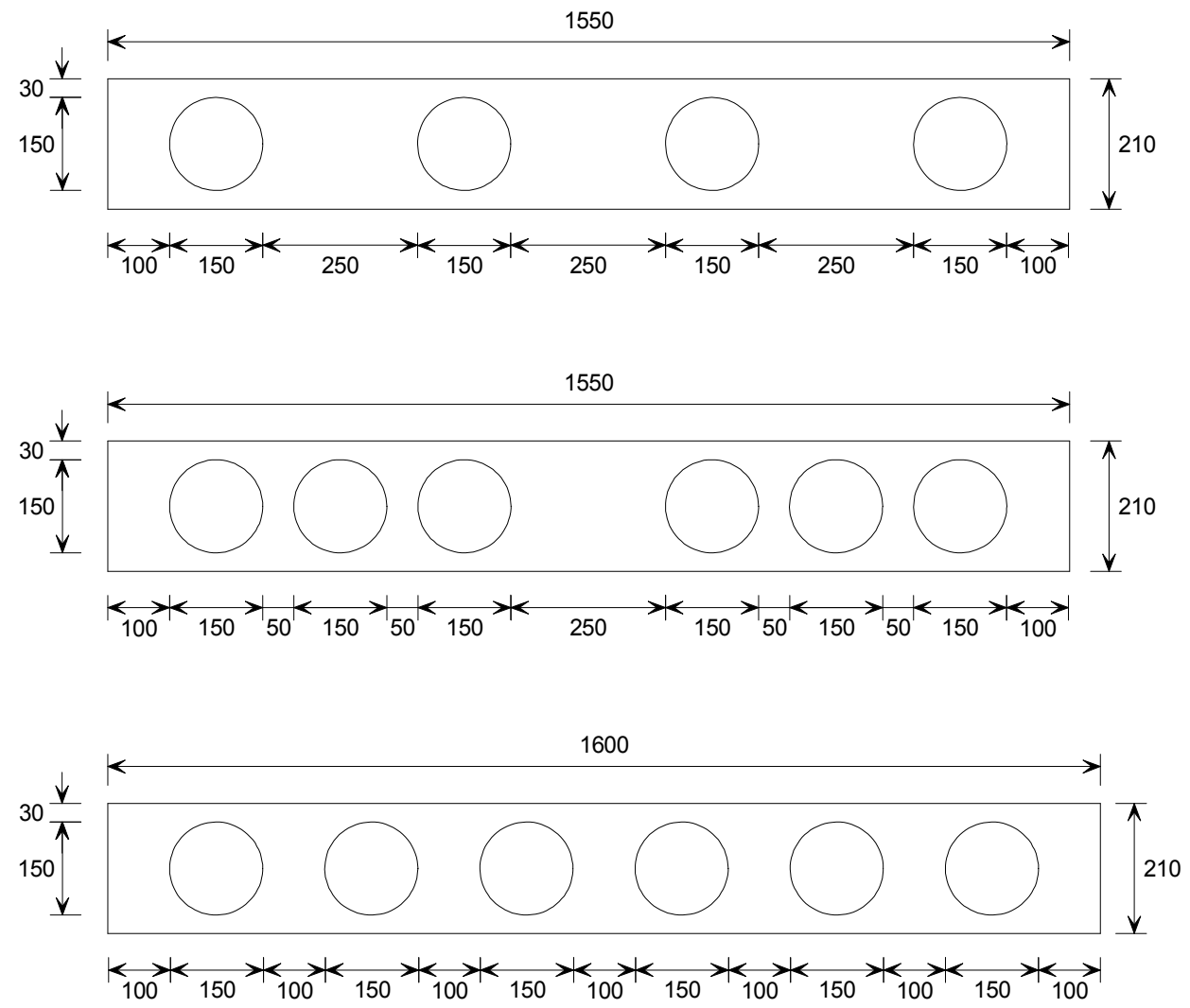

Figure 4 Details of web opening positions in the tests 


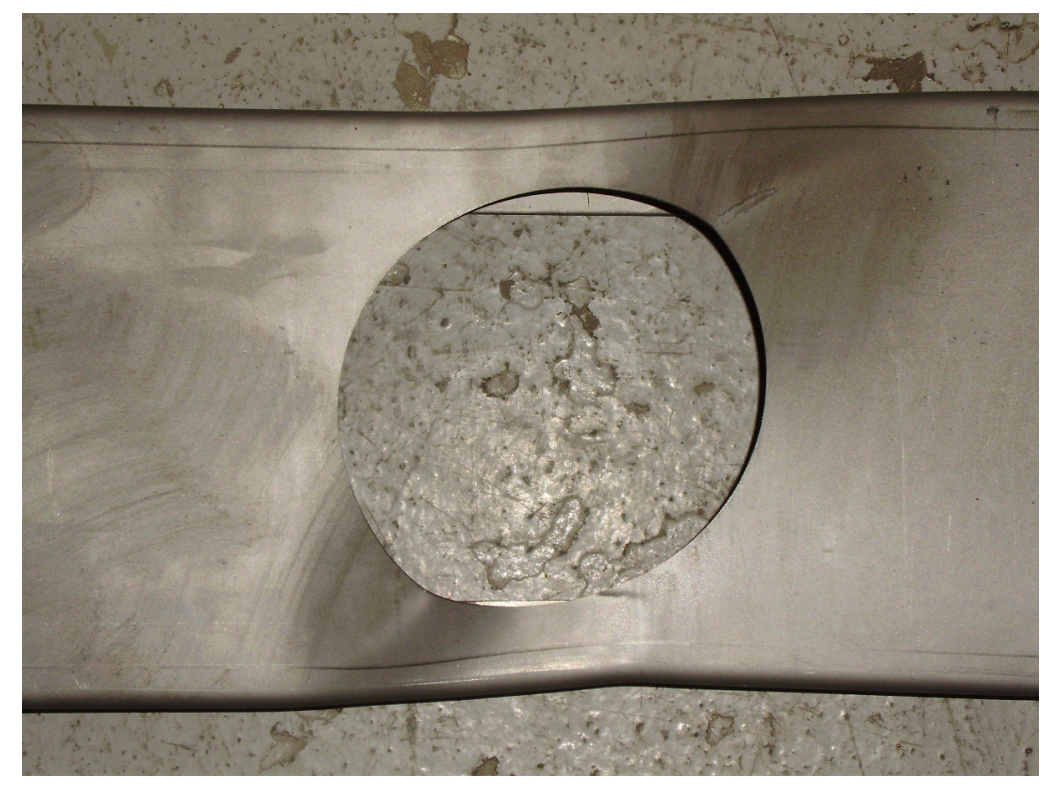

Figure 5 Mode of failure by Vierendeel bending around the isolated opening causing local buckling - Test 1 (after the test) placed on the lab floor

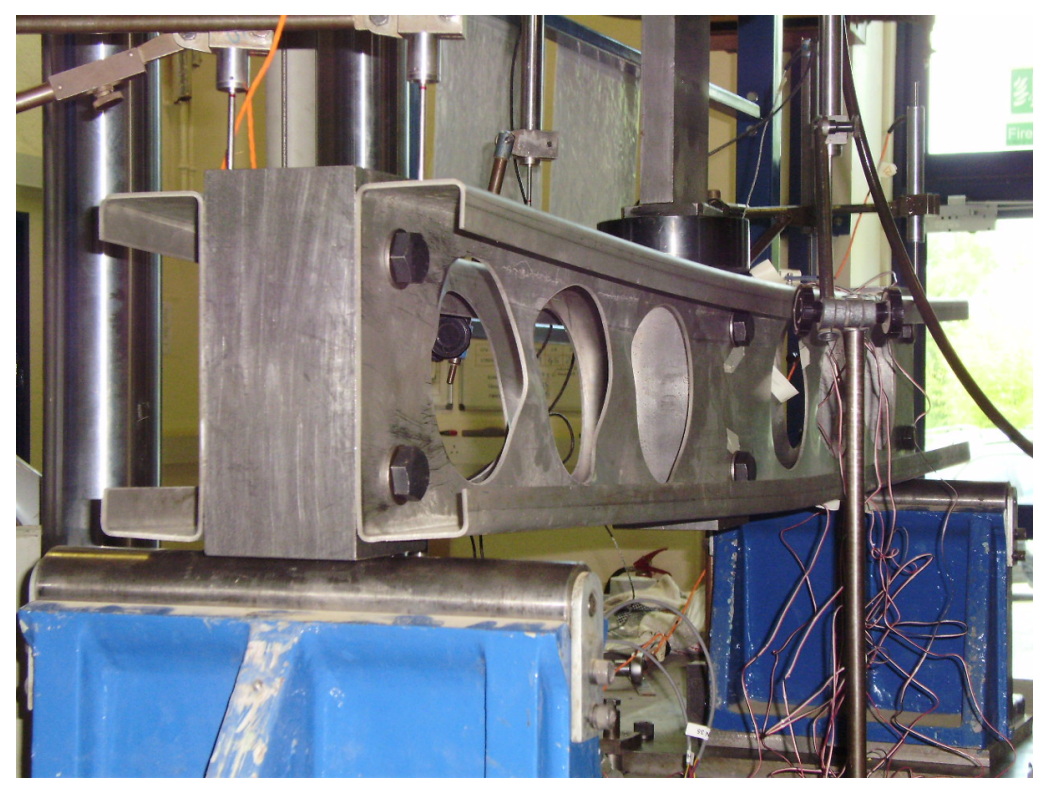

Figure 6: Mode of failure by web-post buckling with closely spaced openings- Test 2 with $50 \mathrm{~mm}$ opening spacing 


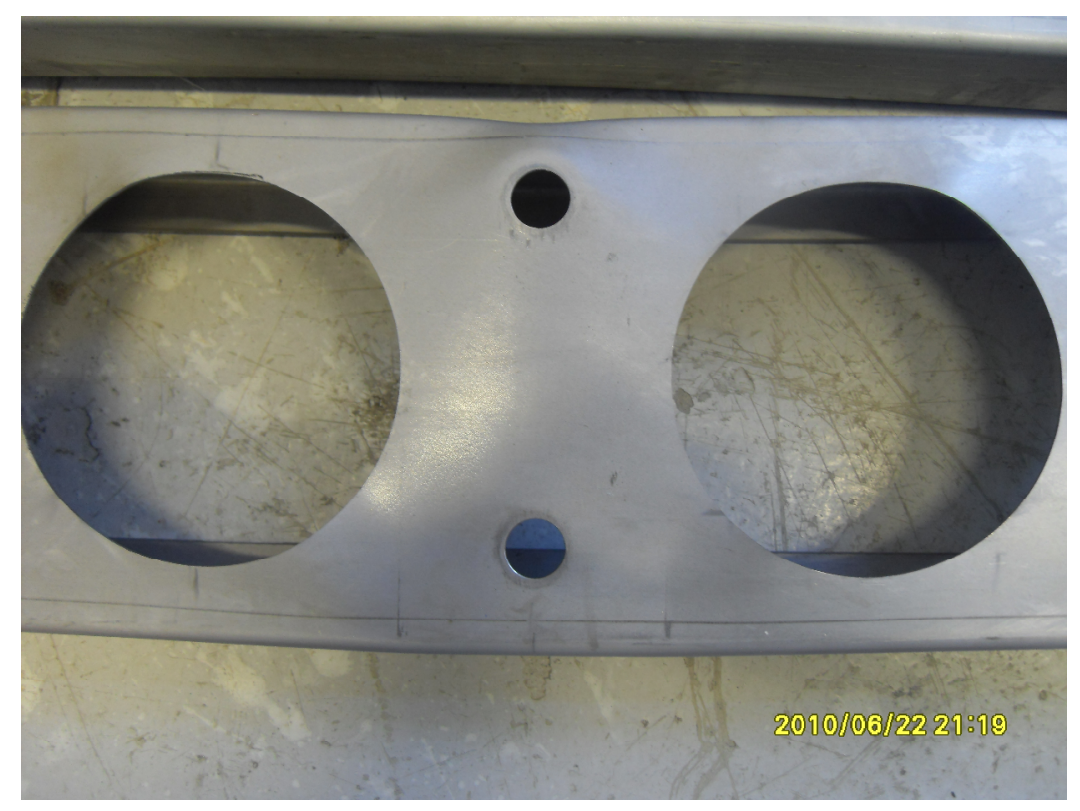

Figure 7: Mode of failure by local buckling failure around the bolts at the load point Test 3 with $100 \mathrm{~mm}$ opening spacing

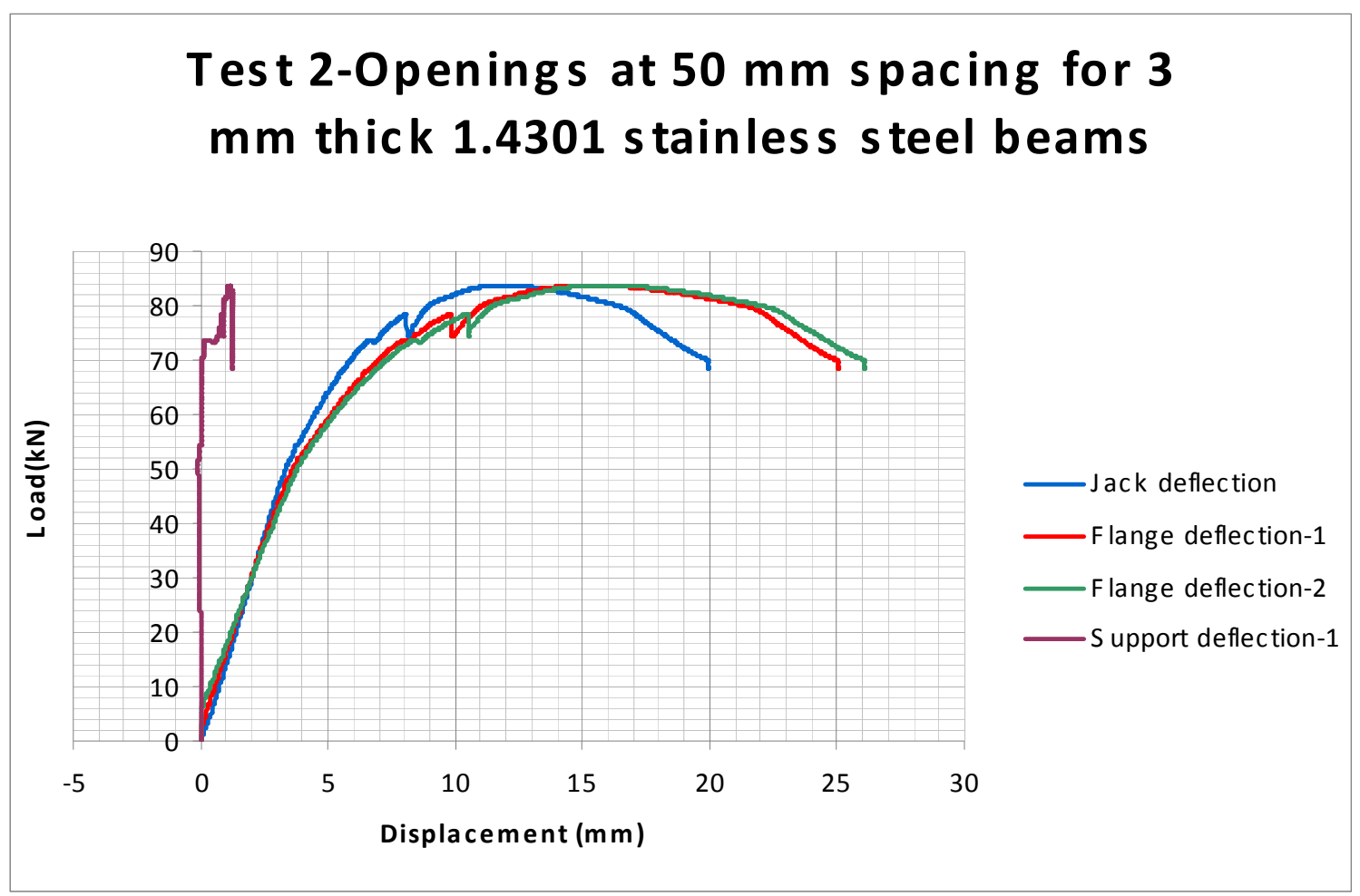

Figure 8 Load-displacement for test 2 using 3mm thick steel and closely spaced openings 


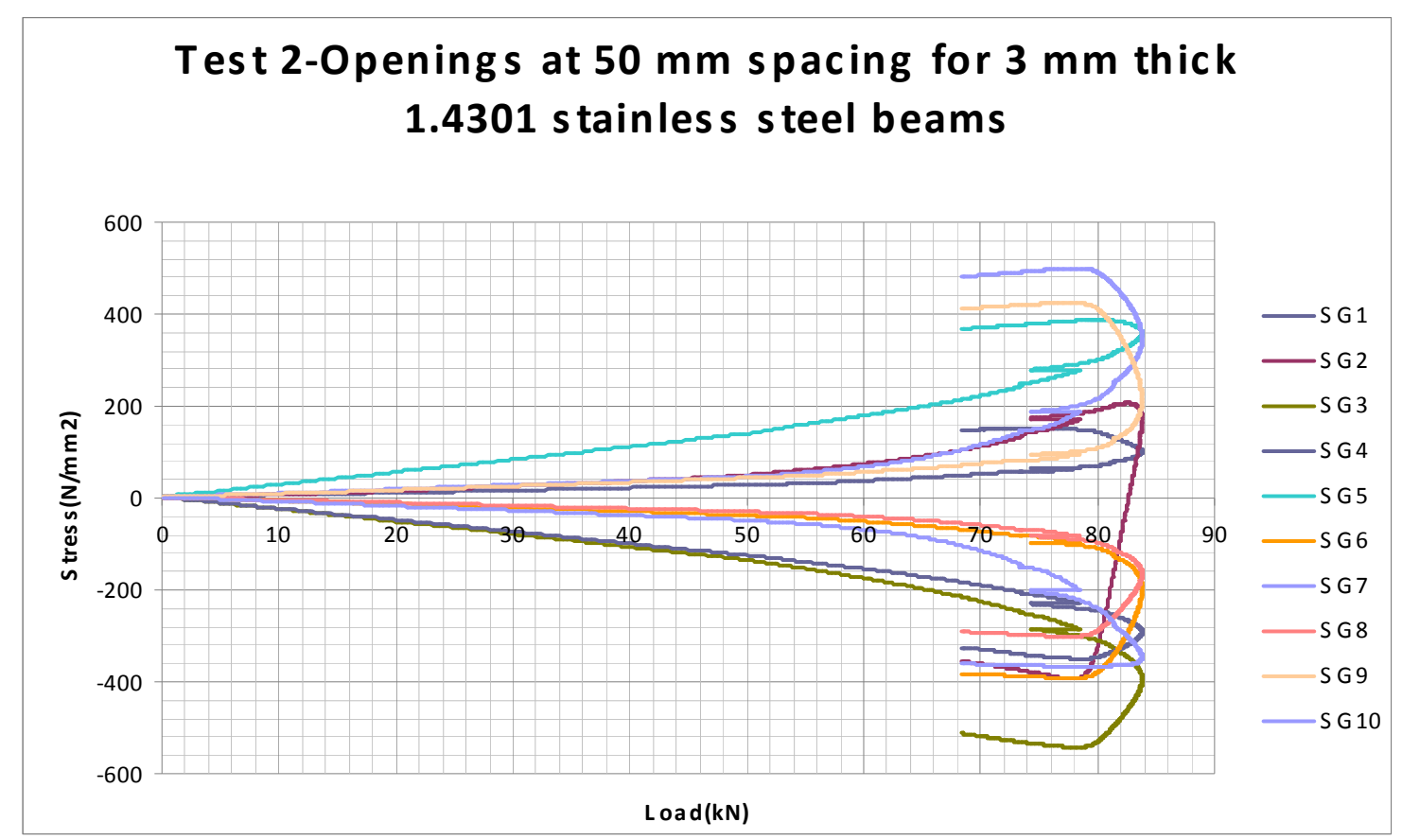

(a) Stresses around the openings

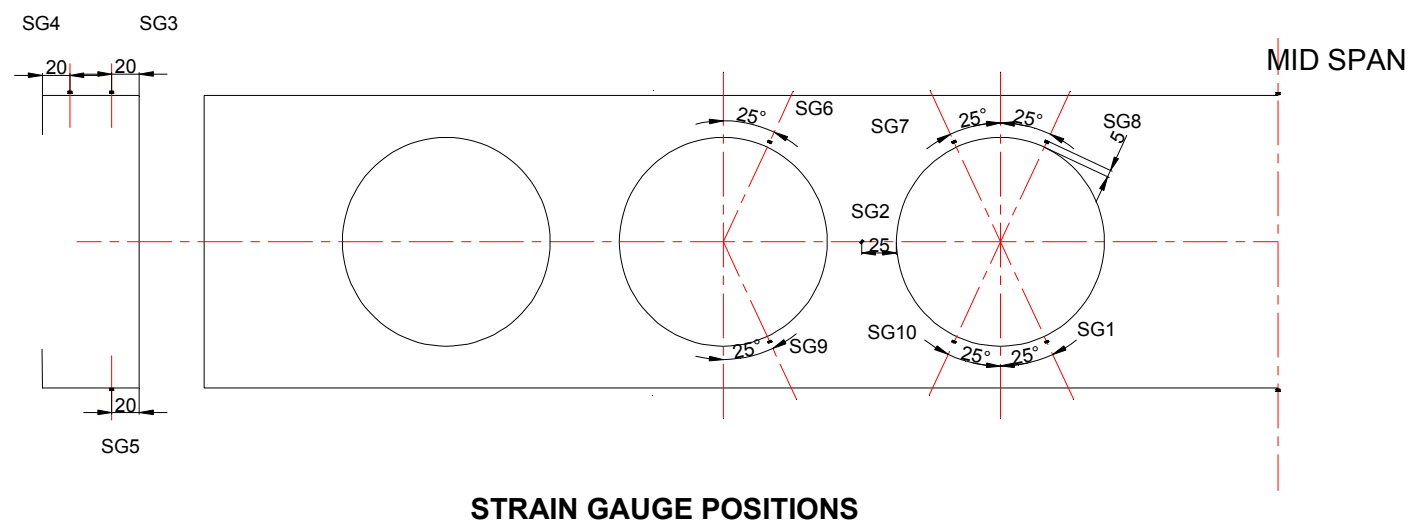

All dimensions are in $\mathrm{mm}$

(b) Location of strain gauges in test 2

Figure 9 Local stresses measured in the test using 3mm thick 1.4301 steel with openings at $100 \mathrm{~mm}$ spacing 


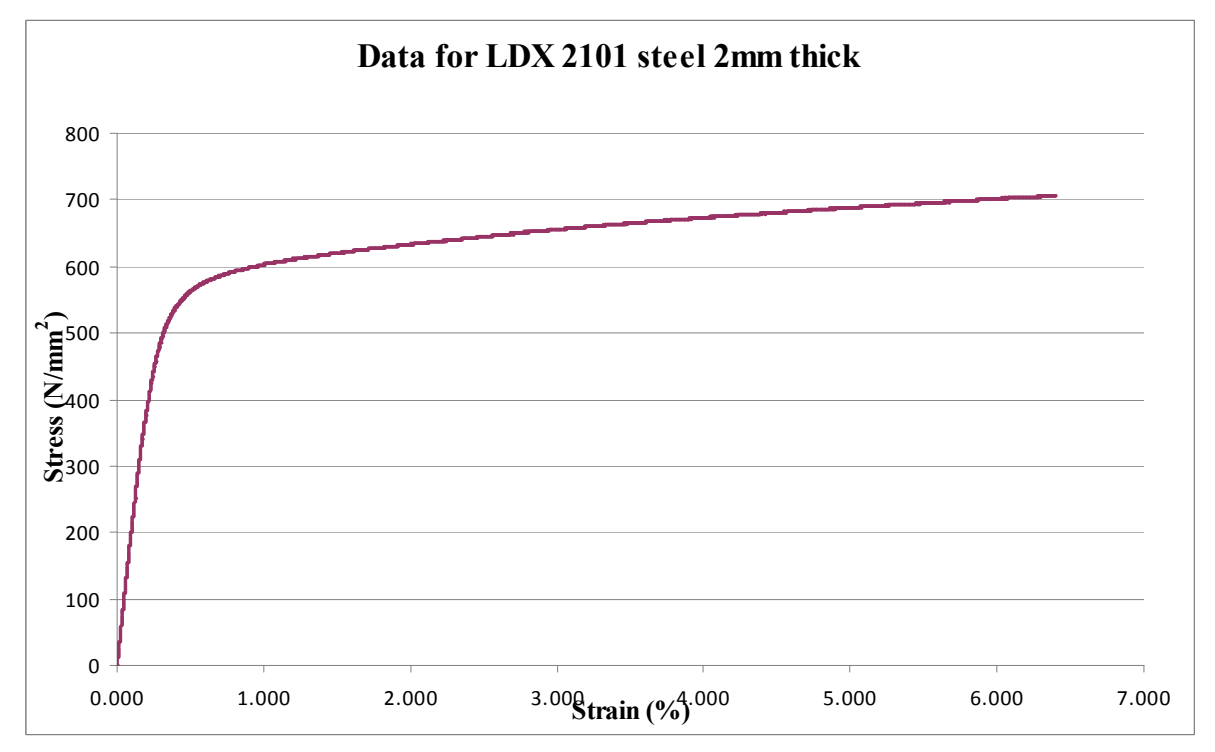

Figure 10 Stress-strain curve for $2 \mathrm{~mm}$ thick 1.4162 stainless steel (trade name LDX $\left.2101^{(\mathrm{R})}\right)$

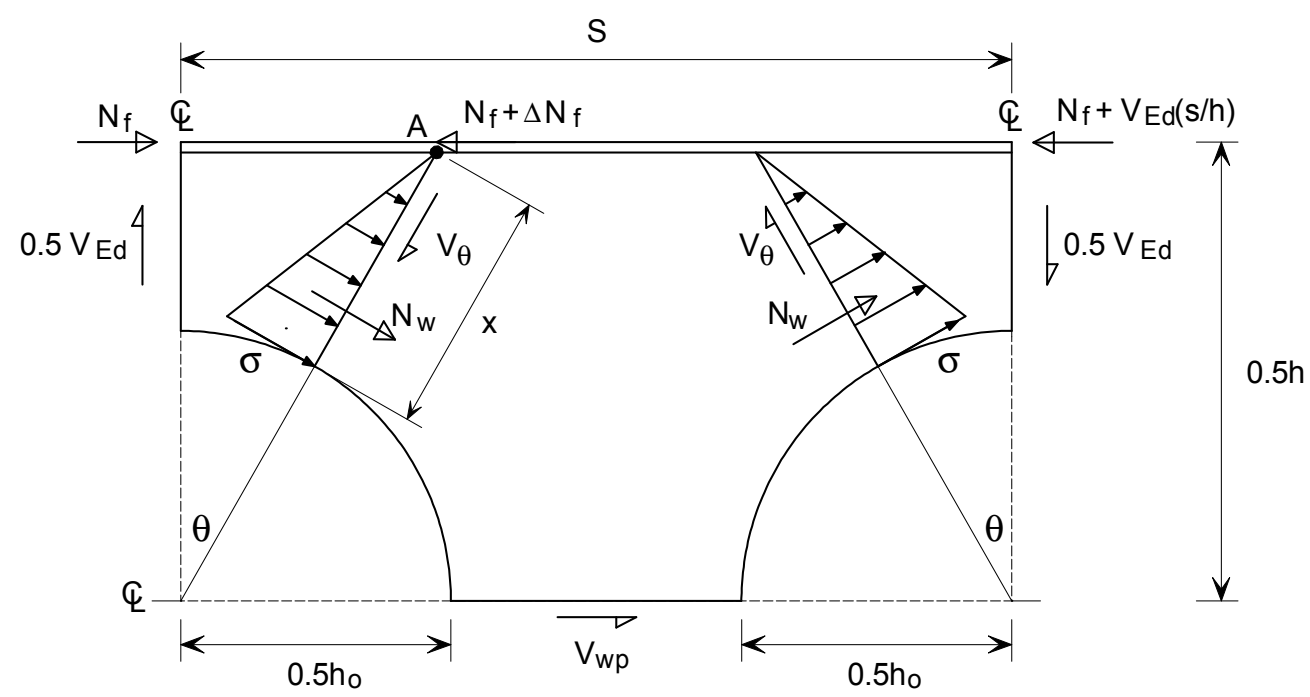

Case 1: $\theta \leq \tan ^{-1}(\mathrm{~s} / \mathrm{h})$

Figure 11 Equilibrium of forces acting on plane $\theta$, when $\theta \leq \tan ^{-1}(\mathrm{~s} / \mathrm{h})$ 


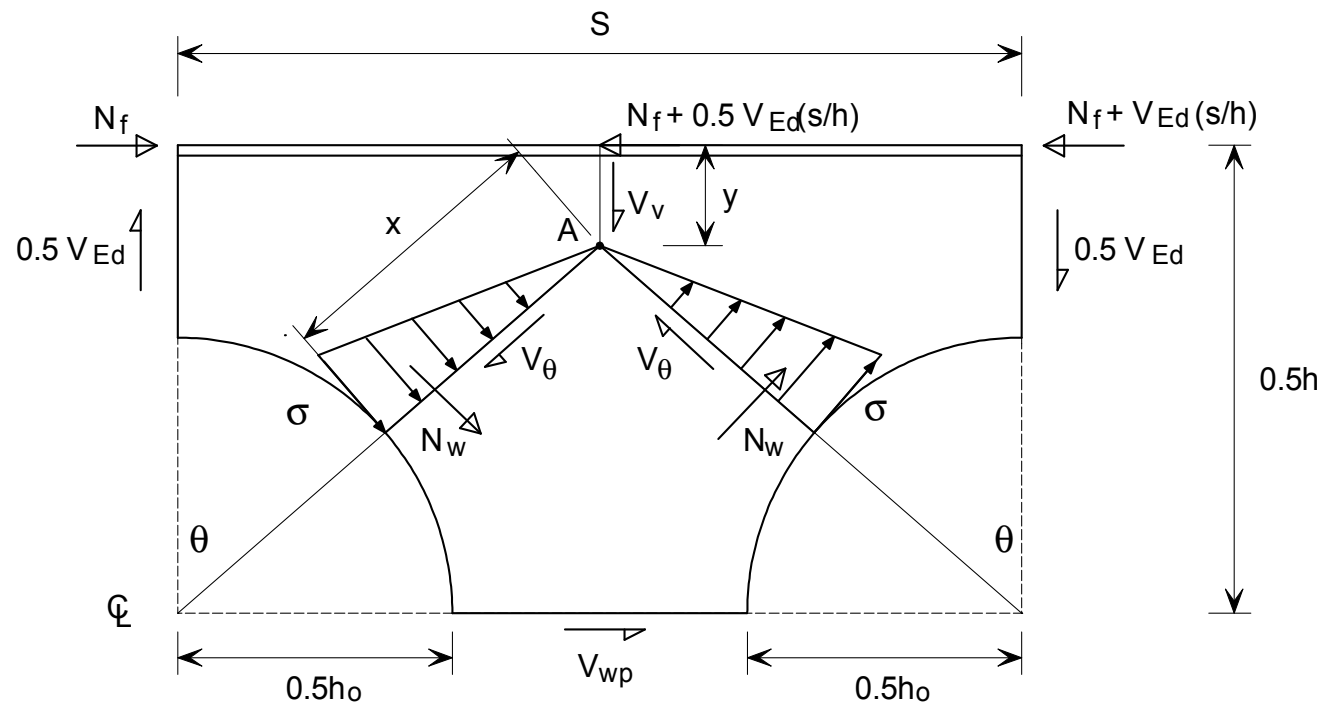

Case 2: $\theta>\tan ^{-1}(\mathrm{~s} / \mathrm{h})$

Figure 12 Equilibrium of forces acting on plane $\theta$, when $\theta>\tan ^{-1}(s / h)$

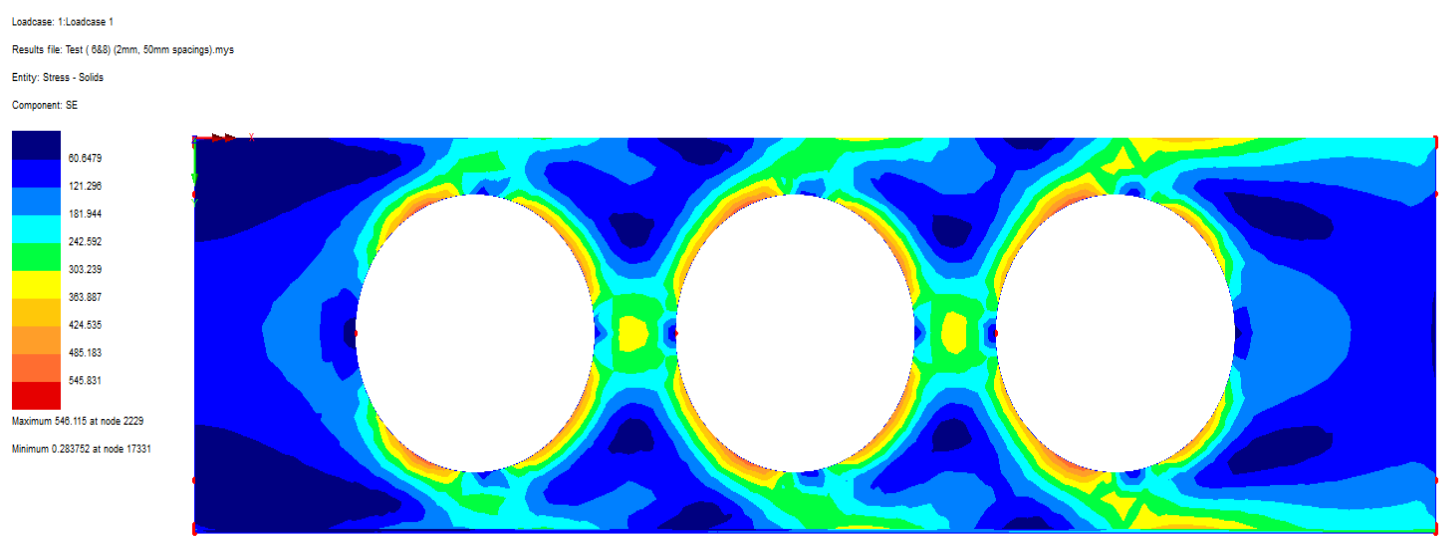

Figure 13: Principal stresses from the FEA at the failure load for the tests on $2 \mathrm{~mm}$ thick lean duplex steel with openings at $50 \mathrm{~mm}$ spacing (support at right hand side) 


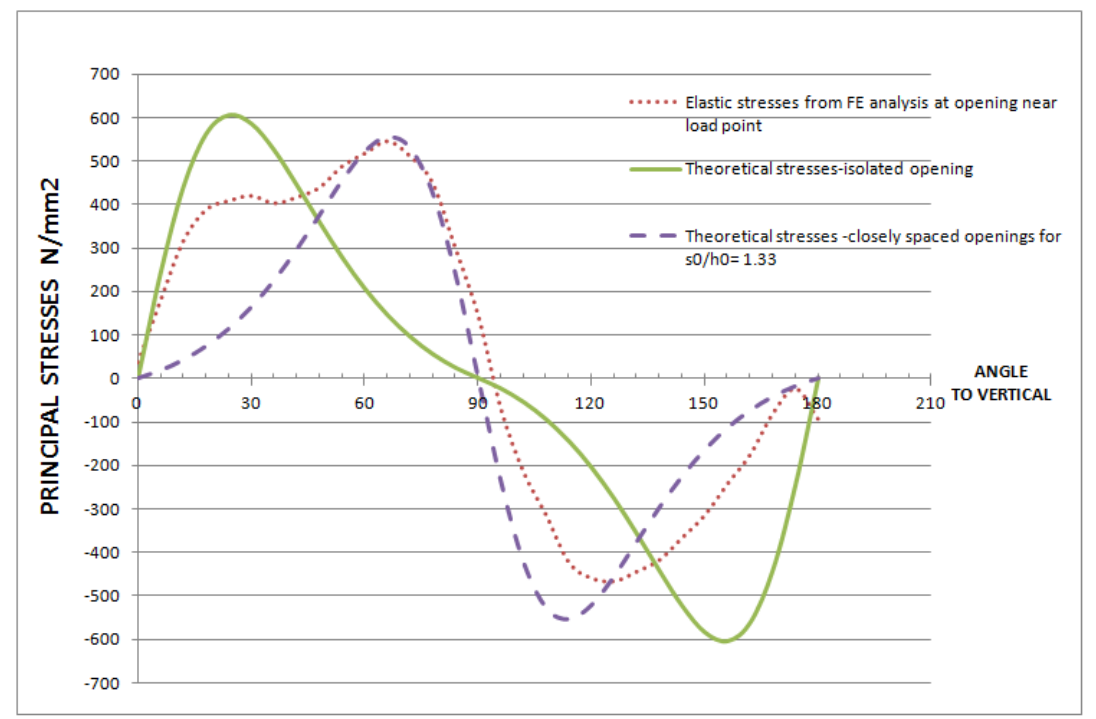

Figure 14: Comparison between the principal stresses around the openings from the FEA at the test failure load and normal stresses from the design method for the tests on $2 \mathrm{~mm}$ thick lean duplex steel with openings at $50 \mathrm{~mm}$ spacing

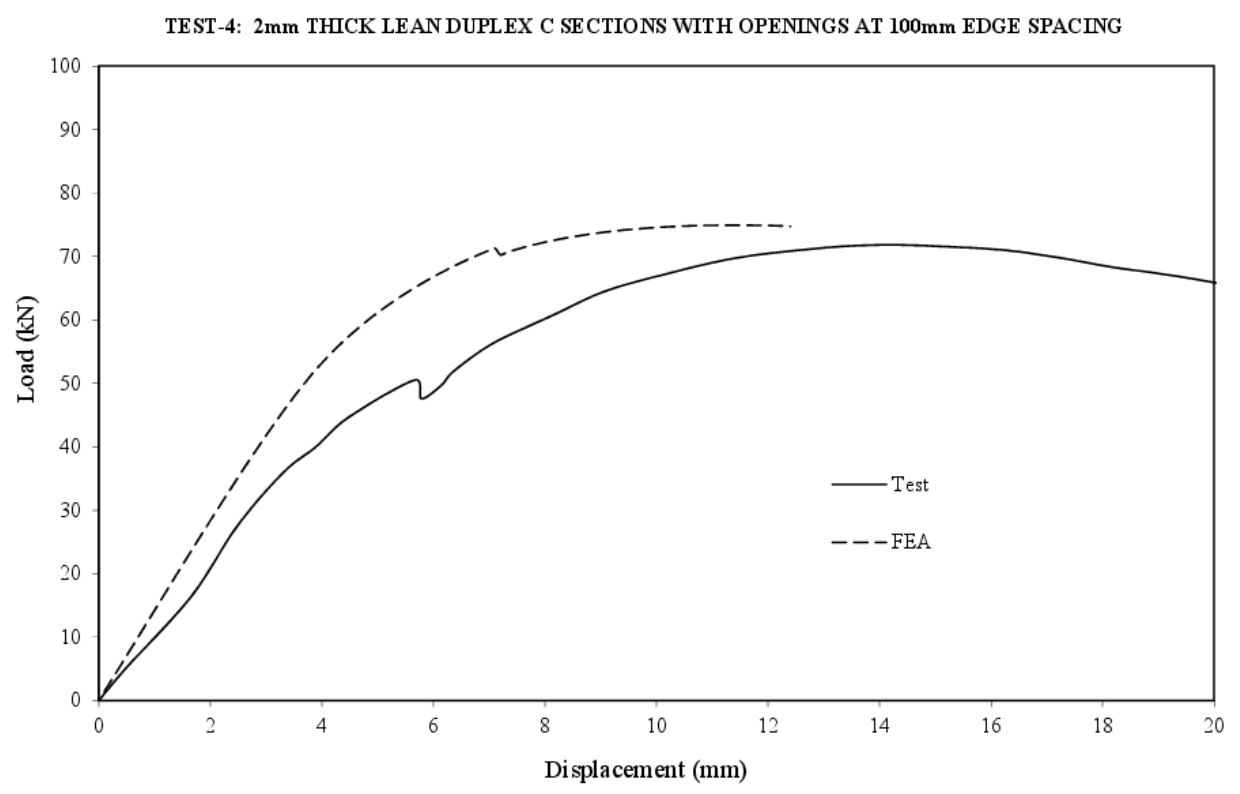

Figure 15 Comparison load - displacement curves for lean duplex $2 \mathrm{~mm}$ thick steel with openings at $100 \mathrm{~mm}$ spacing 


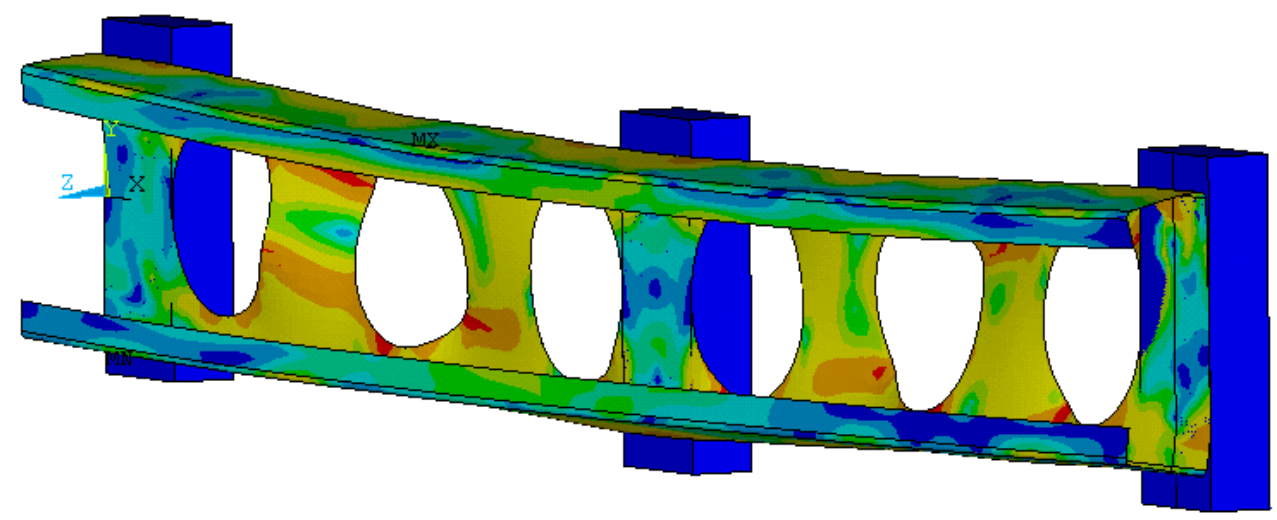

Figure 16 Buckled shape and stresses $2 \mathrm{~mm}$ thick lean duplex steel with openings at $100 \mathrm{~mm}$ spacing 